Historic, Archive Document

Do not assume content reflects current scientific knowledge, policies, or practices. 


\section{NATIONAL FORESTS in}

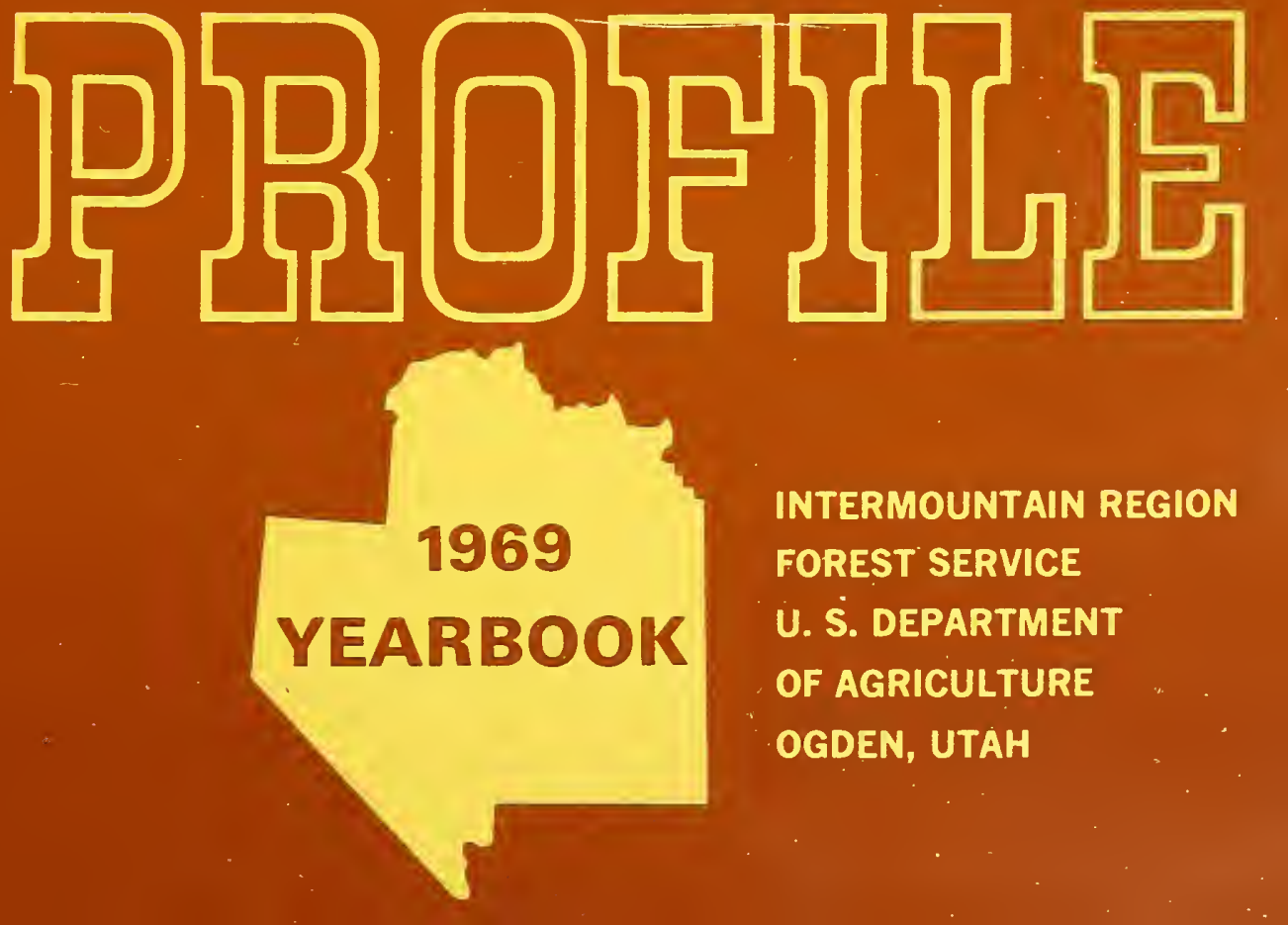
FOREST SERVICE U. S. DEPARTMENT OF AGRICULTURE OGDEN, UTAH 


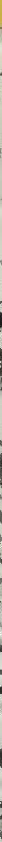
\%

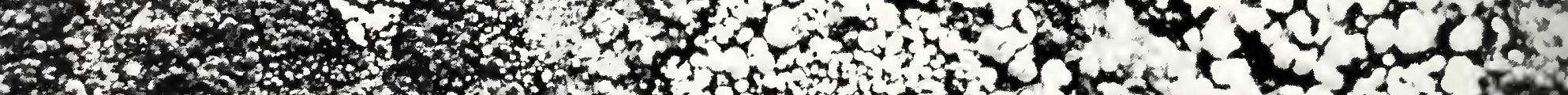

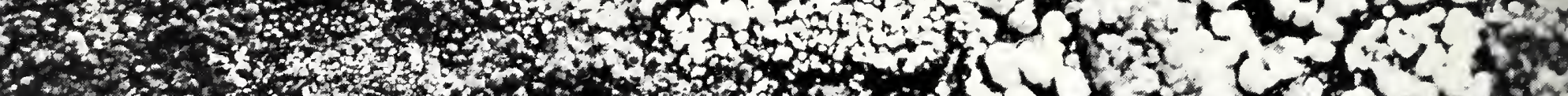

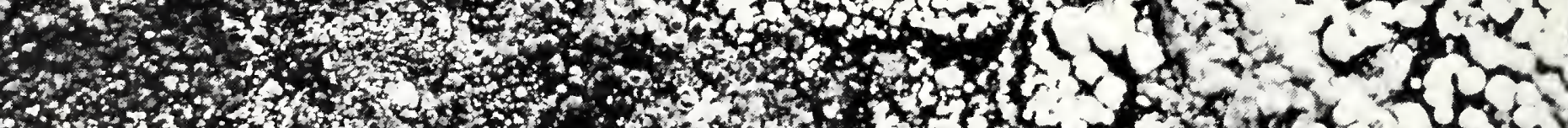

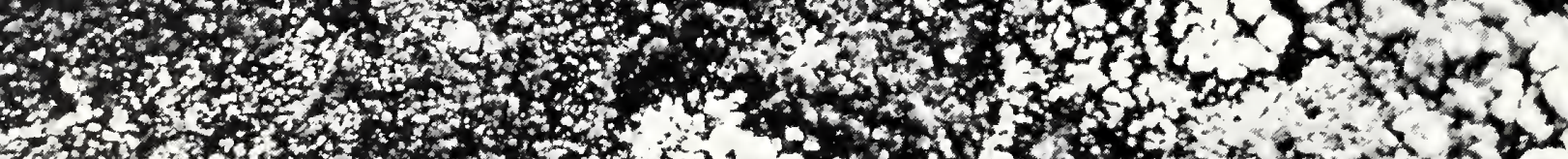
36.

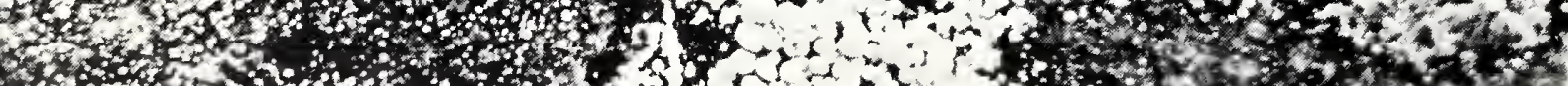
t 6.1, 4 3 3 , 3.73

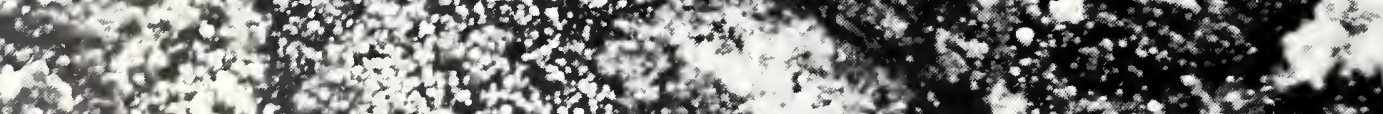
(7)

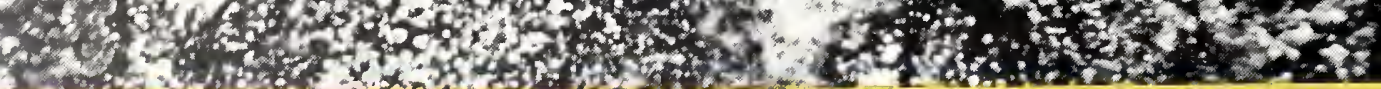

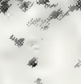

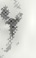

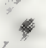
$+$ 
We in the Forest Service are entrusted with a portion of the people's inherited wealth of air, water, land, and life forms. Most of these resources are not confined by geographical boundaries. The water in a river sometimes flows past homes, farms, and industries after leaving or before entering a National Forest. The evening air of the mountains could have been the morning air of a smoggy city. Insect infestations, plant diseases, and fire have no respect for man-made border lines. Thus, Forest Service responsibility extends beyond boundaries, to all people who use the land.

In a world transformed almost beyond recognition during the past century, we are aware that space is limited and resources are exhaustible. Science and management must unite to conserve and improve the natural resources that determine the quality of our lives.

National Forests indeed belong to everyone and they must be managed with the help of everyone. You are invited to consider here a few examples of land and life with which the Forest Service in the Intermountain Region is involved.

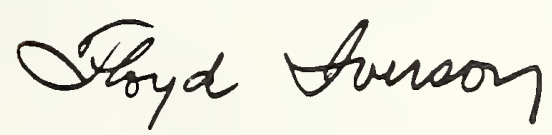

REGIONAL FORESTER 


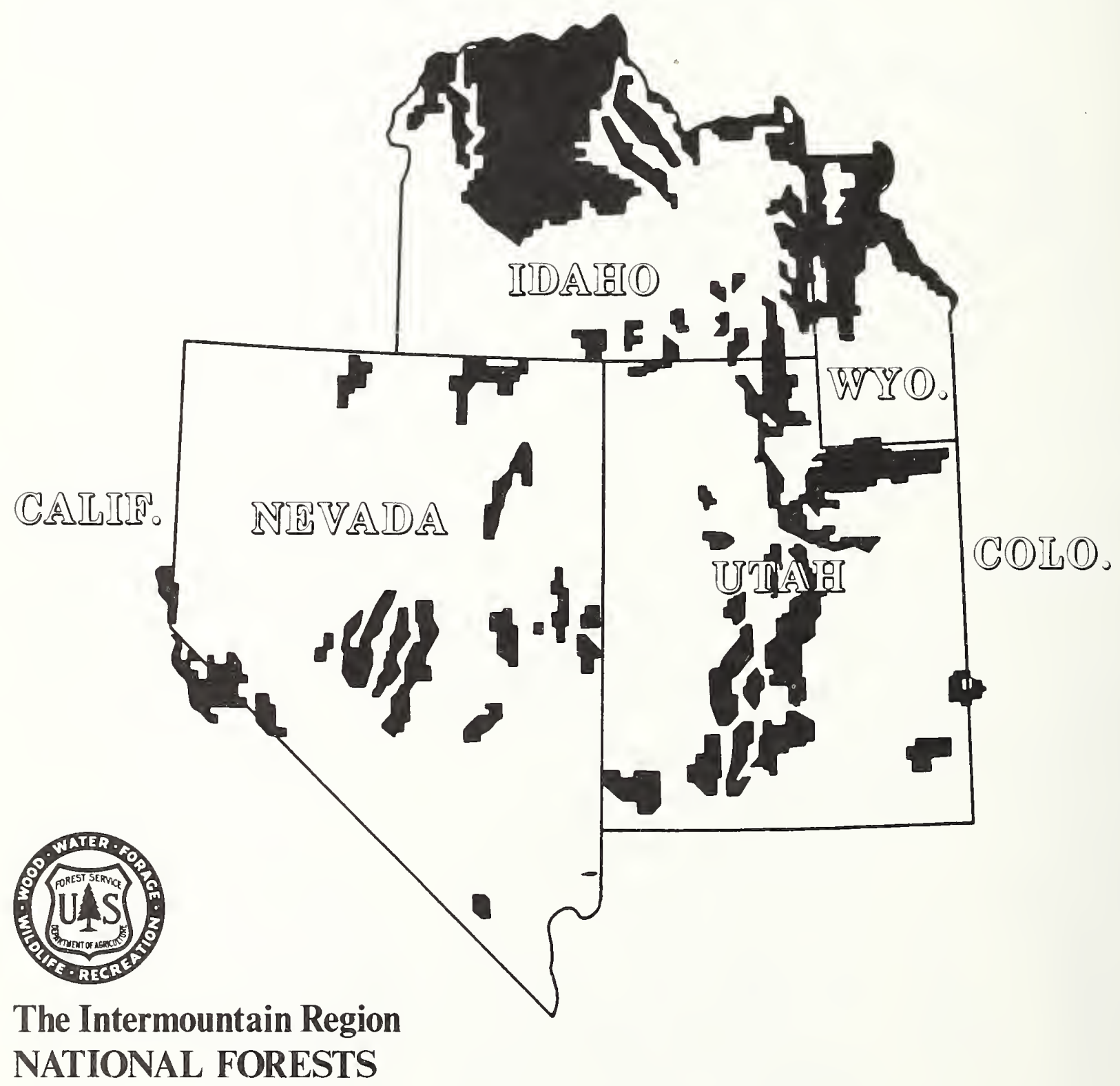


Have you ever looked closely at tiny colorful plants known as lichens? They are found in shades of red, green, grey, yellow, or orange, usually clinging to the surface of rocks or logs. Fragile and temporary they appear, yet lichens were among the first forms of life to survive on this planet. They are still going strong today.

A lichen consists of a fungus and an alga living together in harmony, each contributing to the good of the other. Each depends on the other for survival. Lichens give much to the environment, but they take little in return.

Clinging patiently to a barren surface, perhaps growing only to the size of a quarter in 25 years, lichens help build new soil particles. This is one of the first steps toward the formation of a suitable environment for other plant life and animal life.

This simple pattern of harmony in nature can serve as a guide for us. Of course, as communities of plant and animal life become more complex, the problems also become more complex. Maintaining harmony between people and the land challenges many minds - from land manager to educator, from scientist to philosopher.

Like the poet who sees "the world in a grain of sand and heaven in a wild flower," perhaps in the lichen we can observe the pattern of harmony that is a key to survival for all living things. 


\section{A SILENT WORLD}

Leaves drift to the ground. Mushrooms appear suddenly from nowhere, as if by magic. Moss grows on the undersurface of a rock, and fresh-water shrimps are seen floating near the shore of a stream. A snowflake with a pattern of its own joins billions of other snowflakes - each with a pattern of its own. This silently moving world of nature goes unnoticed by many people, yet what happens to each species of plant and animal life, each crystal of snow or droplet of water, and each particle of soil, ultimately affects the quality of our environment.

The Forest Service resource manager recognizes how his actions and the actions of others can affect the balance of nature and determine the direction of human life. Everything in the world, in some way, is hitched to every other thing. Each link forms part of the endless chain.

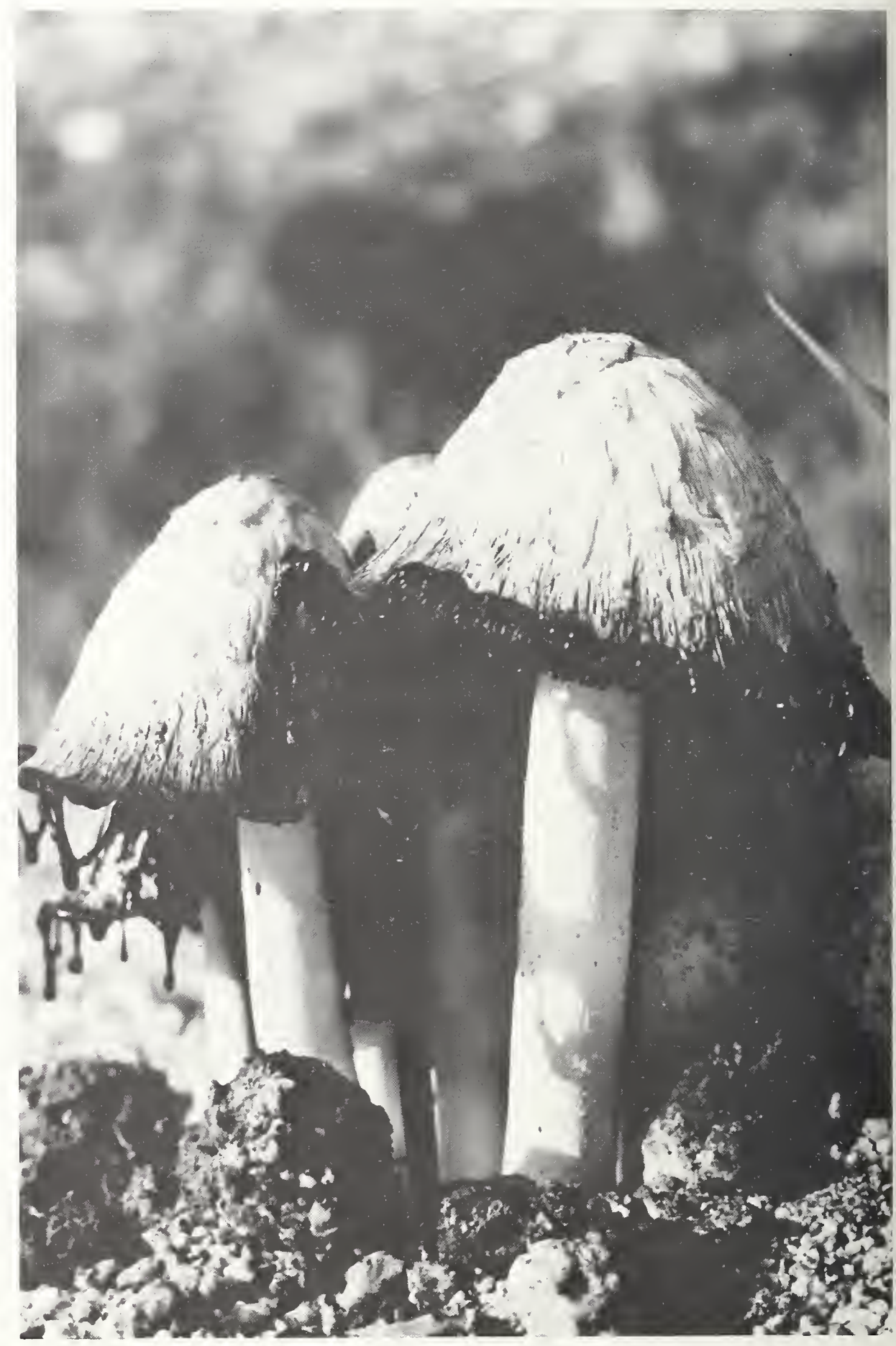



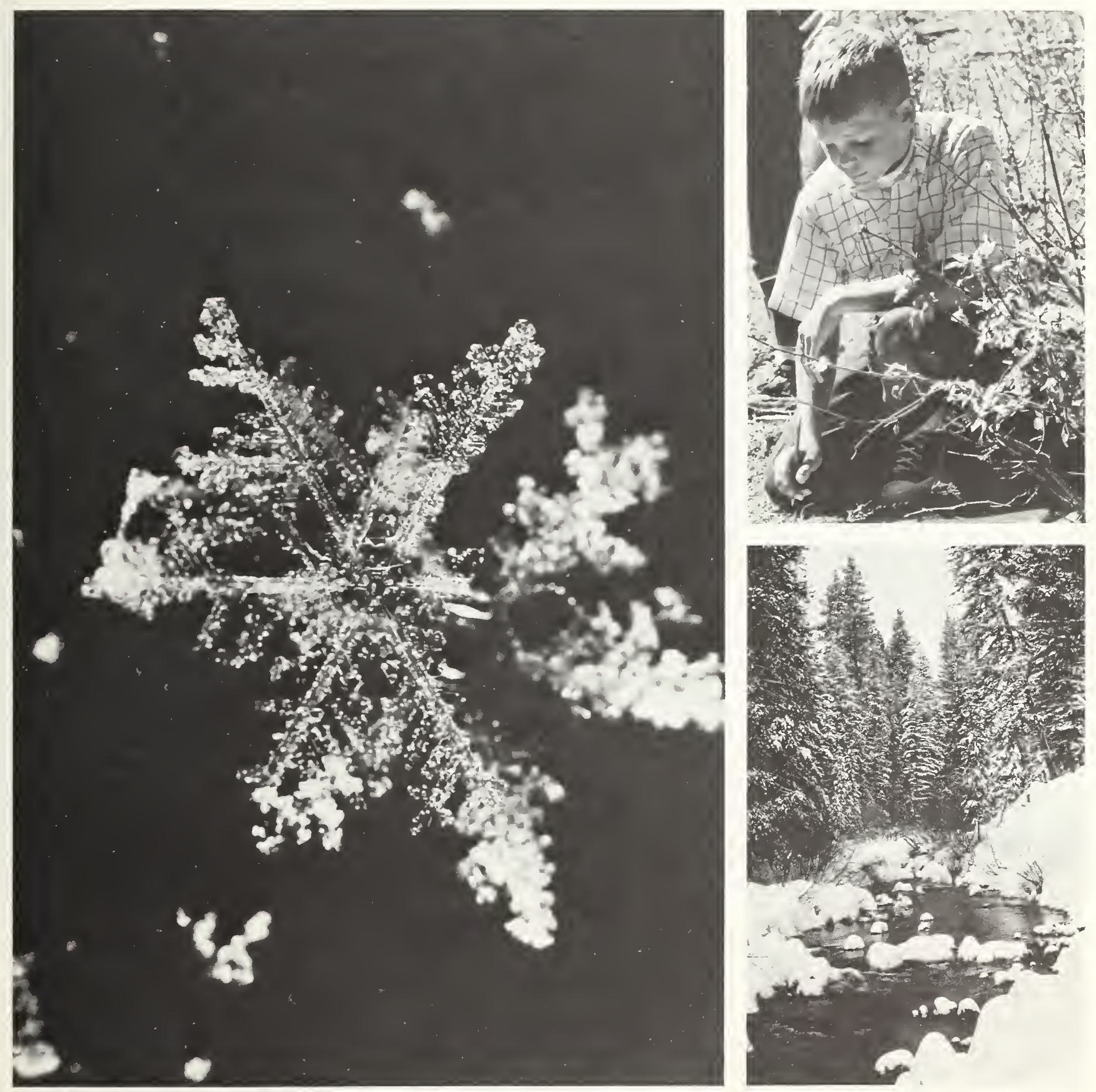
The chain of life links together plants, insects, animals and even man himself. Each inhabitant of the earth interacts with the air, water, and soil upon which survival depends. The nature of things includes both life and death.

In the forest a seed sprouts and a tree begins to grow. During its growing years the tree provides food and shelter for birds and small animals. It gives protection to the land. If the tree is not harvested, it will in time be destroyed by fire, insects, or disease. The dead tree will slowly decay and enrich the soil to promote the growth of more trees.

Management of National Forests requires that some trees be harvested so that new trees can grow in their place. Other trees will remain unharvested. Forest managers base these decisions on silviculture needs, economics, and ecology.

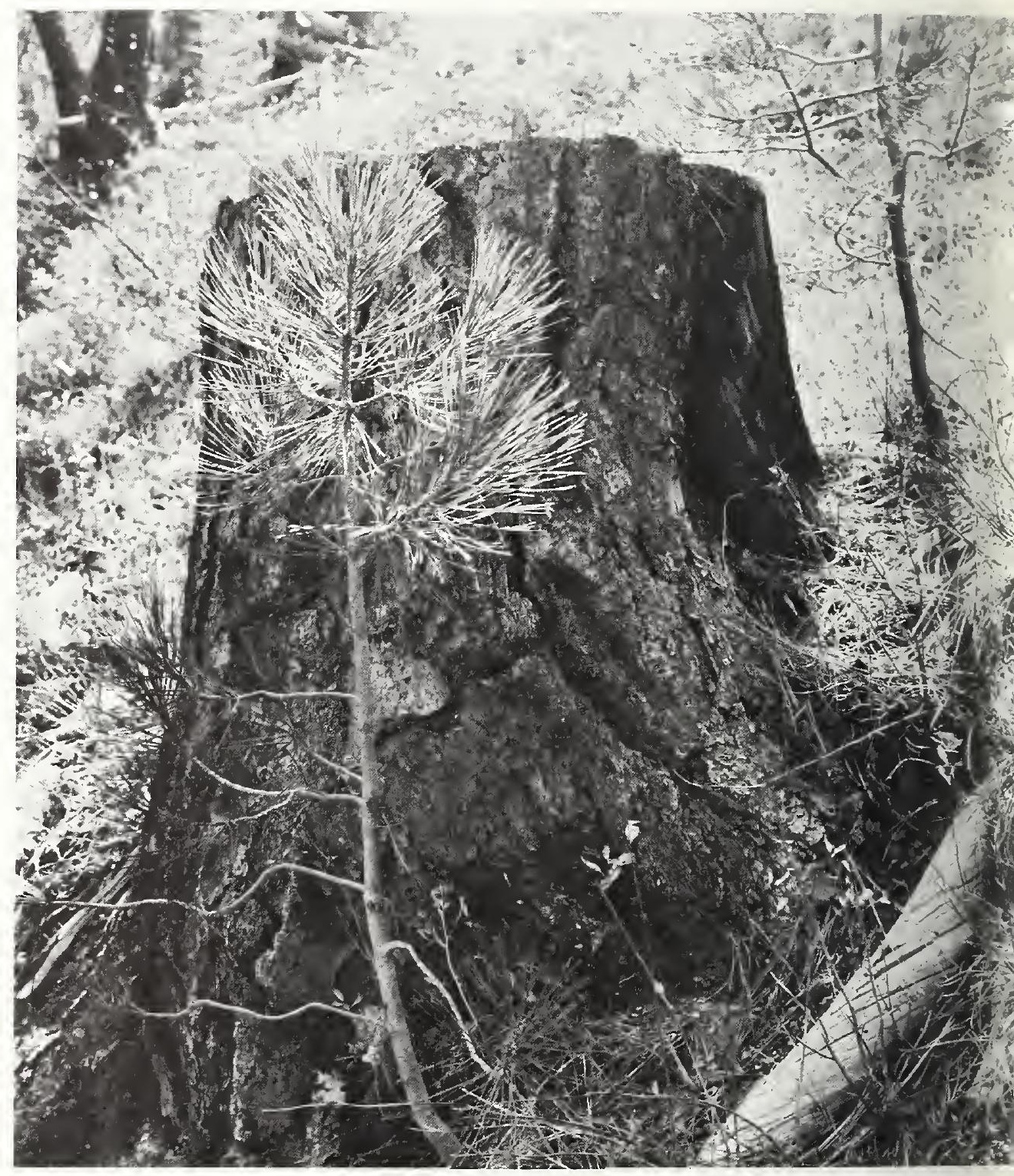



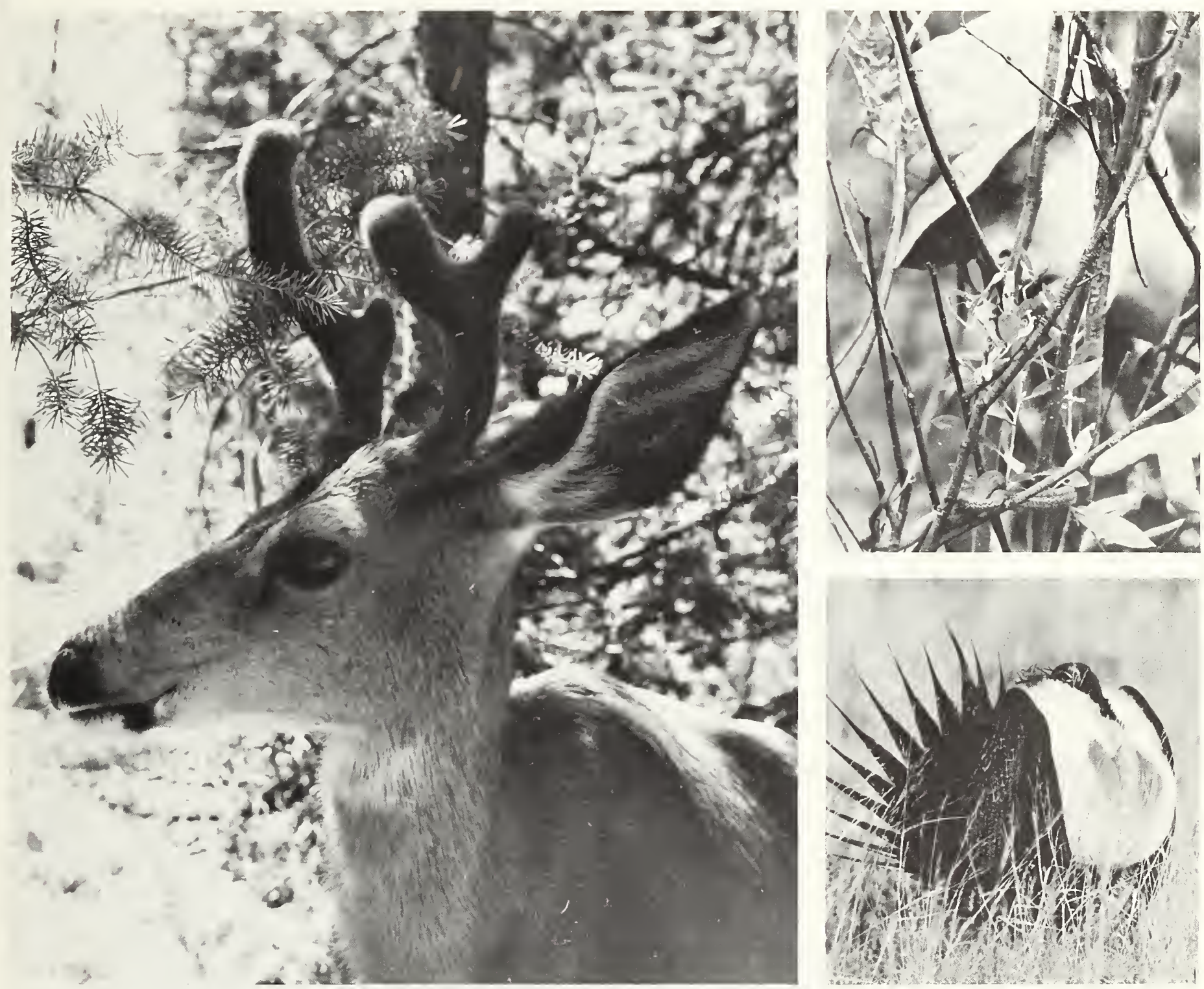
No scene remains unchanged for more than a moment in geological time. Even in wilderness areas set aside by the Forest Service, forces are constantly at work building mountains, carving valleys, and channeling rivers. Through our lifetime most wilderness scenes appear unchanged, and their rivers flow wild and free. They are managed to avoid the impact caused by the works of man.

Indian diggings and fossil remains on National Forests of the Intermountain Region are open pages to the past, unlocking secrets of origin and culture. Prehistoric animals and Indian artifacts often alter the course of modern roads and cause building sites to be changed. Significant geological areas are set aside so that everyone will have an opportunity to study the forces at work on this planet.
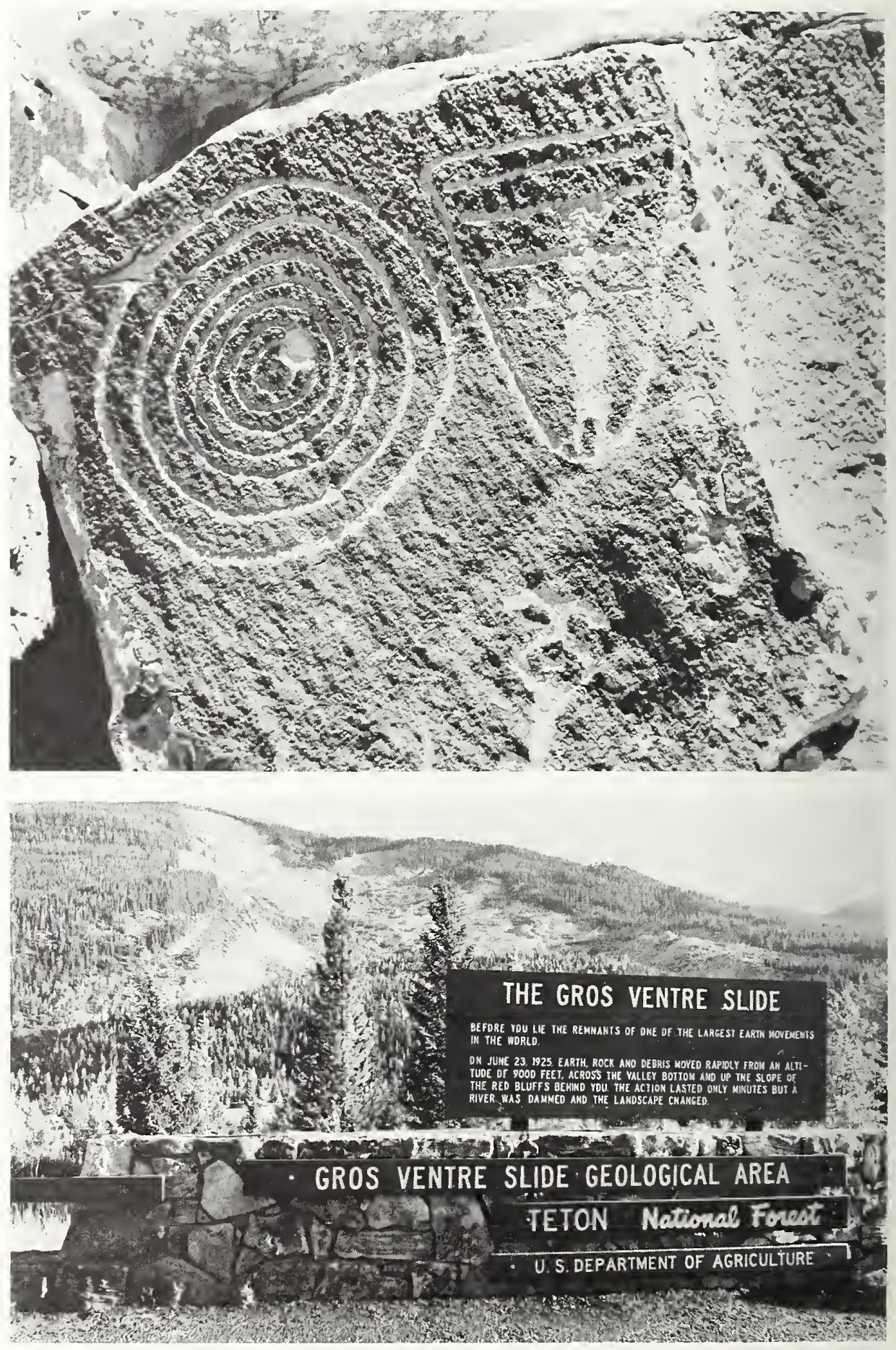

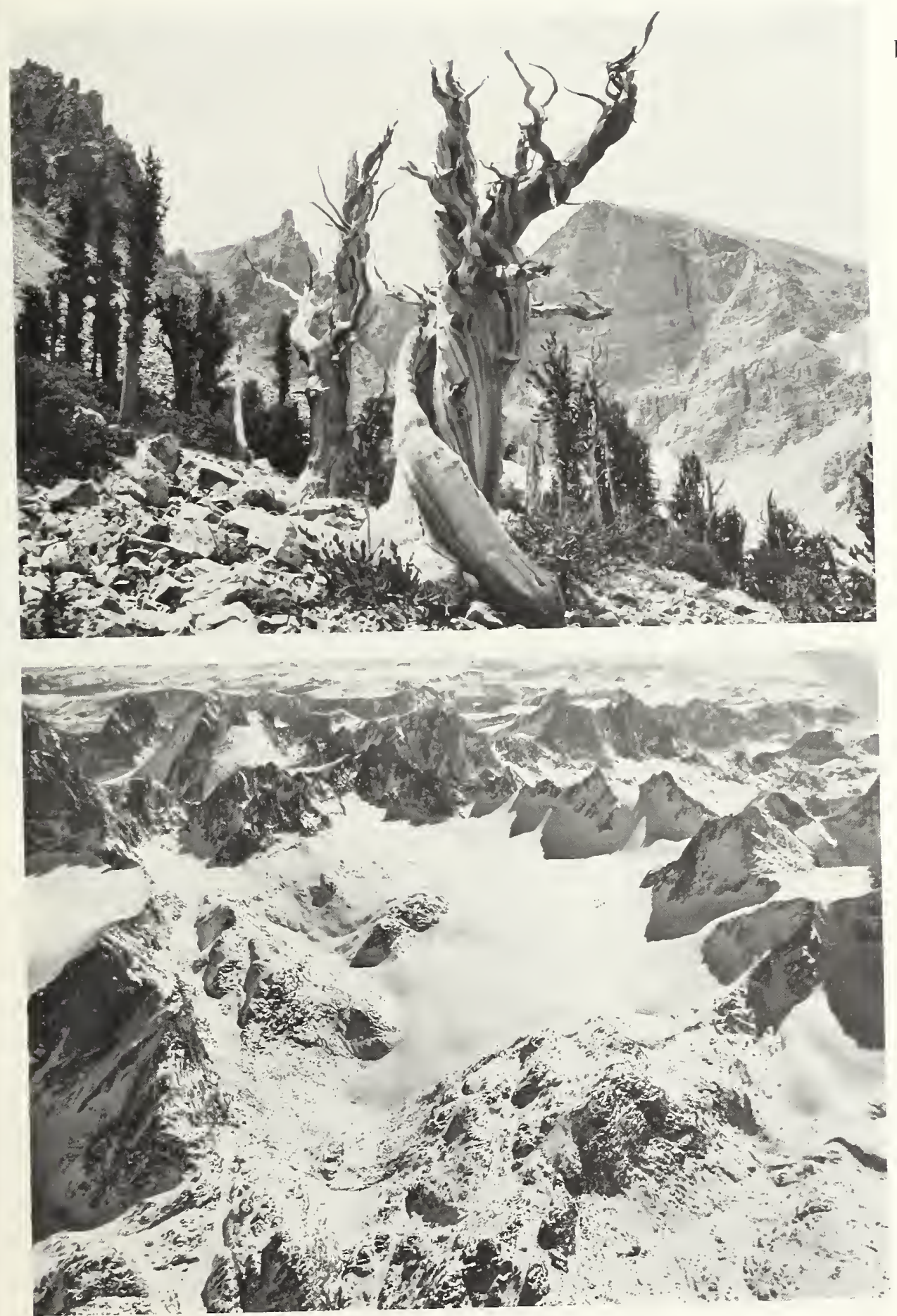

Bristlecone pine in the Wheeler Peak Scenic Area.
Glaciers of the Bridger Wilderness Area. 
People value the wealth of resources, the harvest of crops, recreational opportunities and the many uses of National Forest land. Their activities often result in visible change. When the land is wisely used, changes can be beneficial and often pleasing to the eye. When land use is unwise, people must learn from their errors. Time is the teacher who has shown how to control harvests and balance land uses. The lessons must be studied if man is to maintain and protect the quality of life for all inhabitants of the earth.

National Forests are living, changing communities where scenes cannot remain forever the same. There is a place and a time for grazing livestock, harvesting timber, mining minerals - for building dams, campgrounds, roads, trails, and ski developments just as there is a time and place to defer grazing, refrain from harvesting trees, and do without reservoirs, roads, mines, trails, campgrounds, and ski developments. Decisions must be based on what results in the greatest good for all.
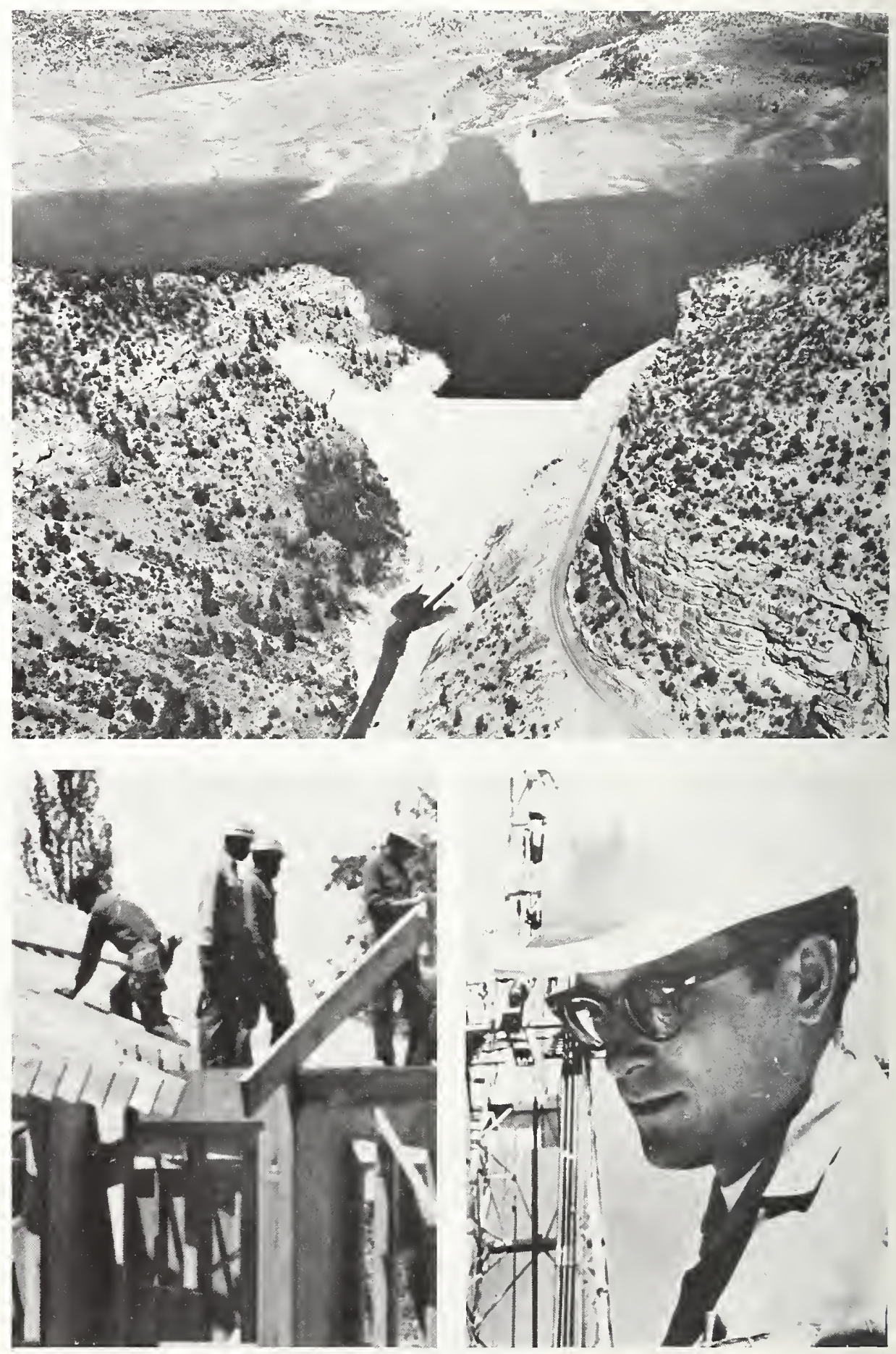
In southeast Idaho, mining companies are working with the Forest Service to find successful methods to rehabilitate strip mined areas. Research to determine suitable plants and growing methods is being carried out by the Intermountain Forest and Range Experiment Station. The photograph shows a view of the spoil dump and contour trenches installed to stabilize overburden at a phosphate mine in Mabie Canyon on the Caribou National Forest.

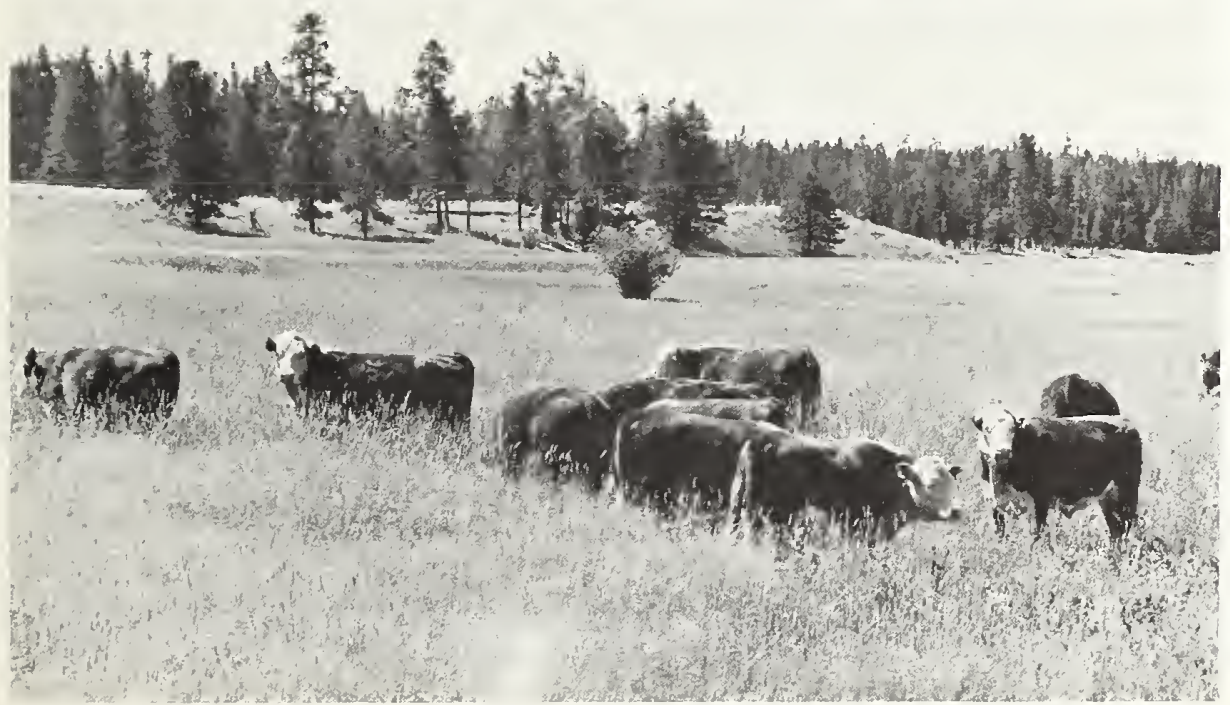


Cooperation between State Forestry Departments, Soil Conservation Service, and the Forest Service was necessary to rehabilitate this damaged watershed that produces municipal water for Carson City, Nevada.

Methods of harvesting mature timber in ways that protect the esthetics and natural resources require the skills of many specialists. Research continues on slash disposal and air pollution problems.
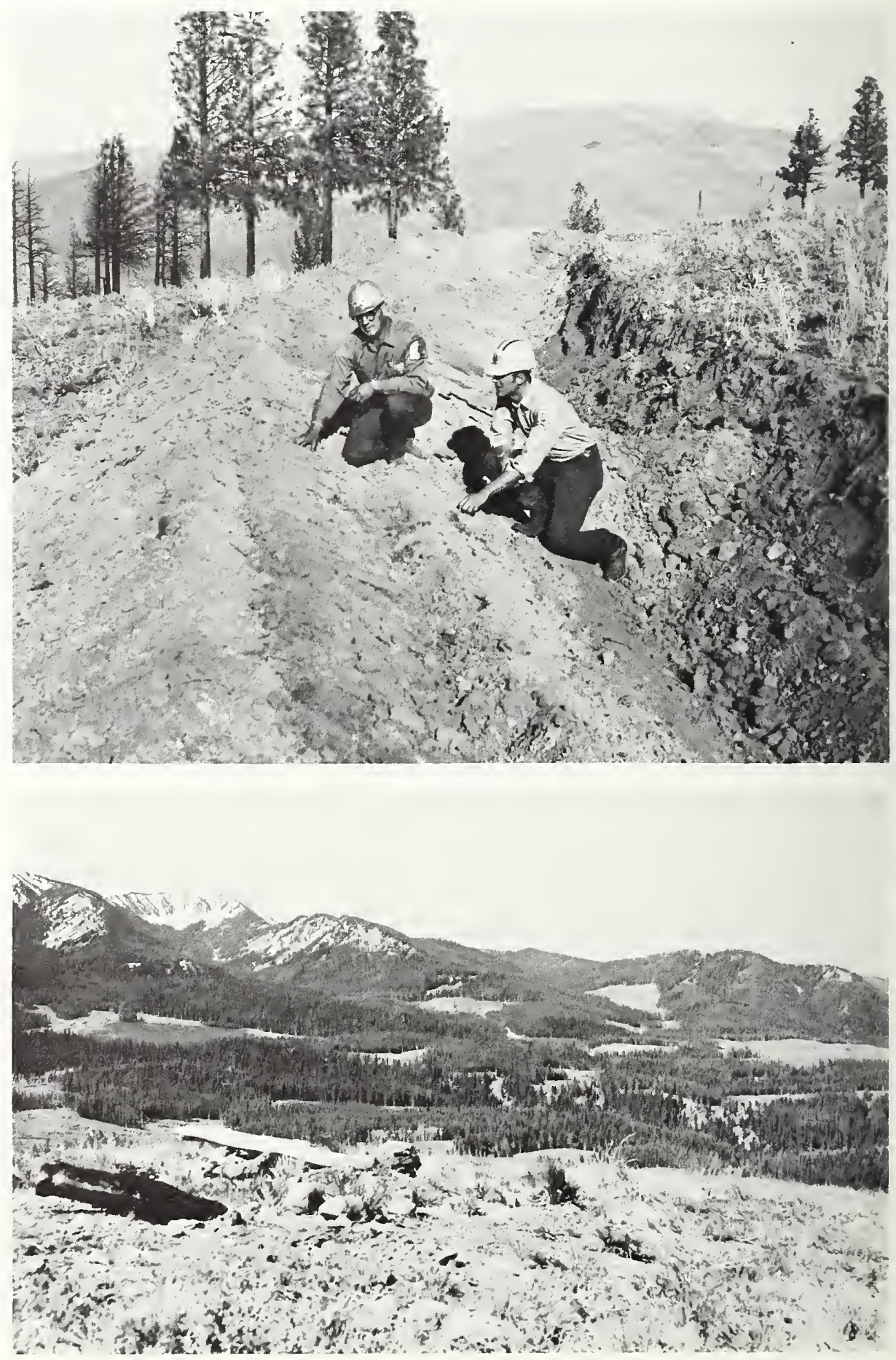
National Forests provide work and livelihood for many people. Play is the nature of some work. Other work involves modern technology and pioneering skills. Play opportunities are improved for the visiting public by the work of fishing and hunting guides, ski area operators, or special use permittees at recreation sites. Loggers, smokejumpers, stockmen, commercial pine nut pickers, or Christmas tree cutters combine the latest in technological development with the earliest of man's working ways.

The lives of all people in the Nation are affected directly or indirectly by National Forests. Consider, for example, the many jobs provided by manufacturers and sellers of sporting goods, ski equipment, and camping gear. Consider also the number of uses of wood products - from place mats to the nose cones of spaceships.

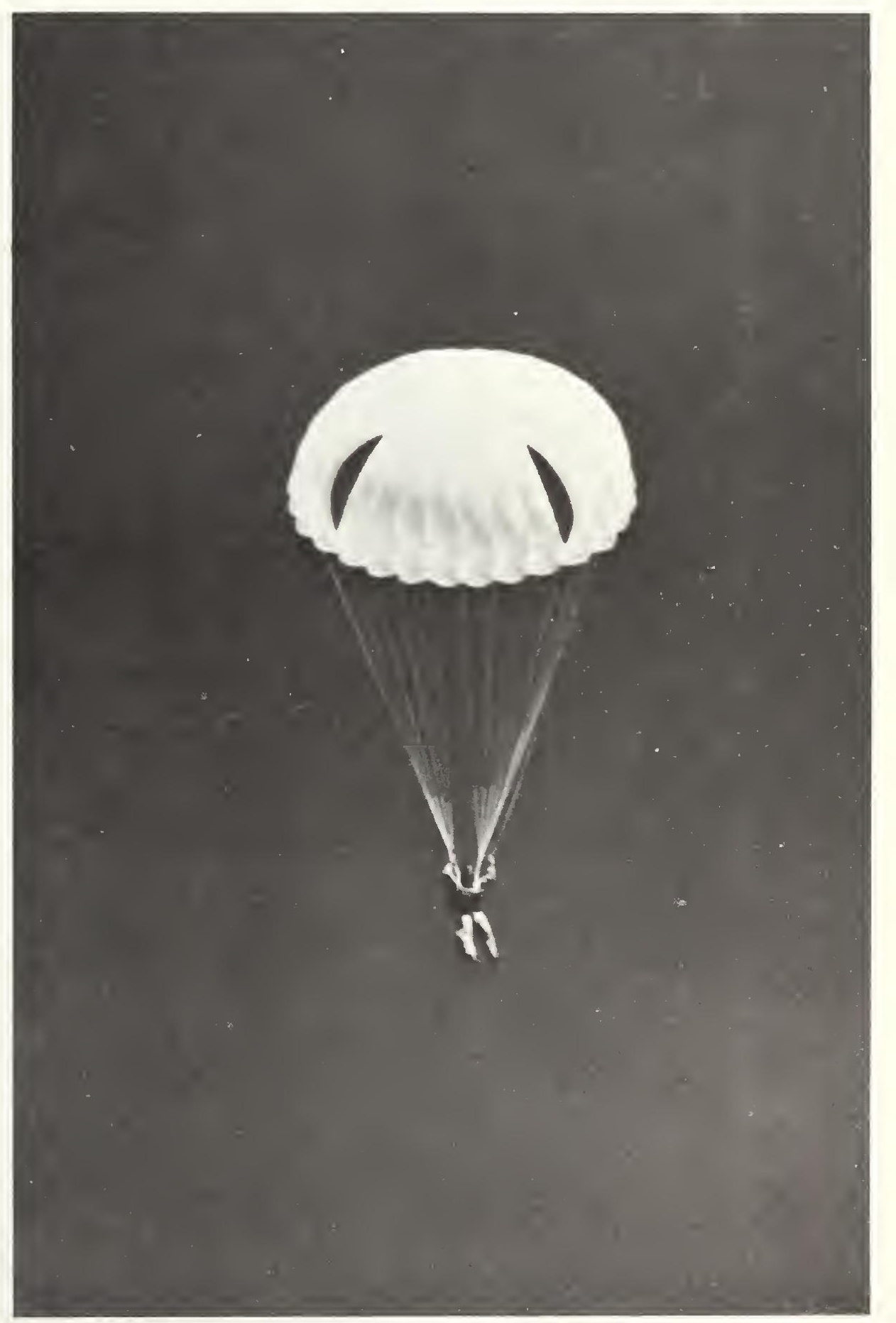


This young lady has a charming way of explaining outdoor etiquette to young campers.

Sorting freshly harvested pinenuts - a skill rooted in antiquity.
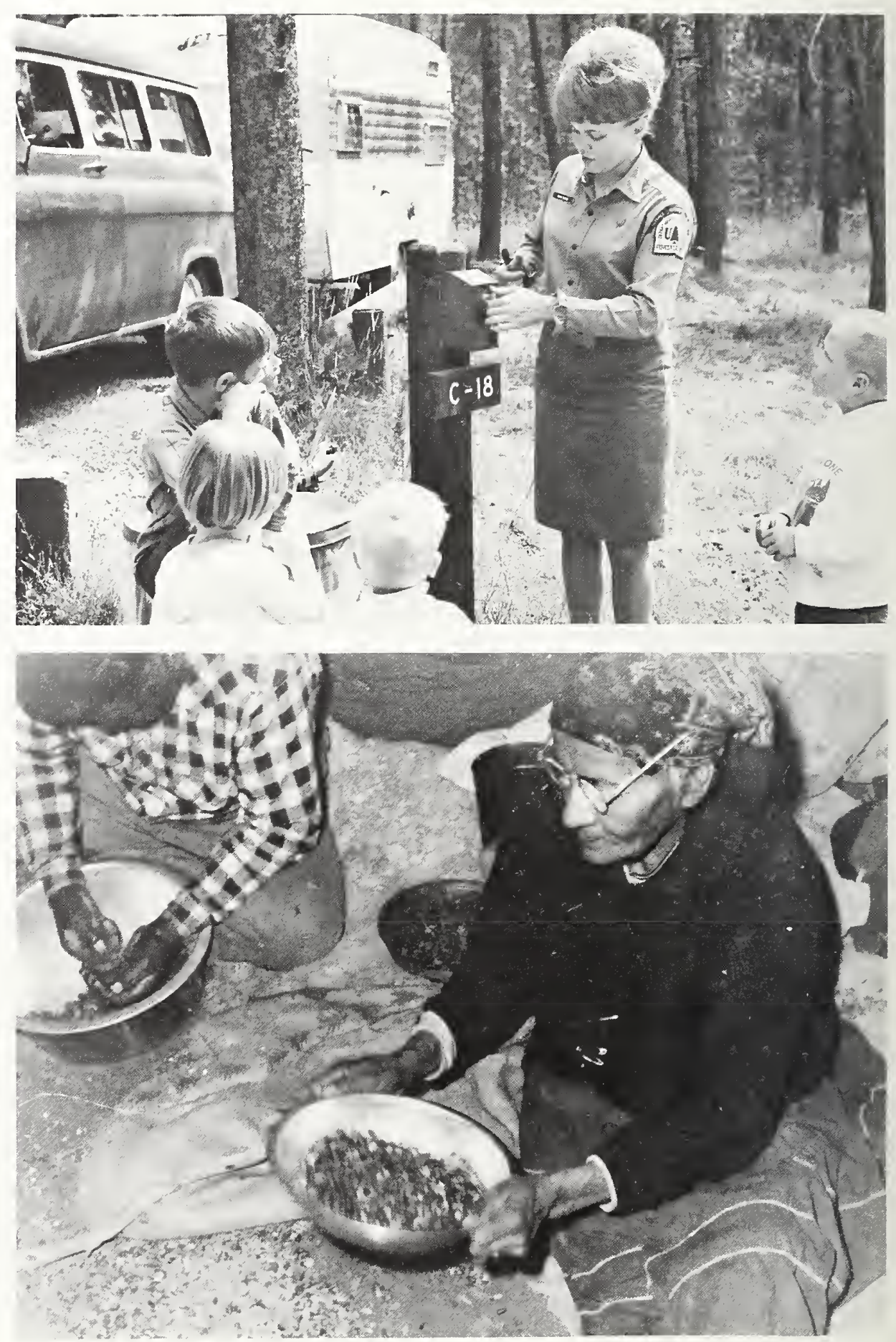

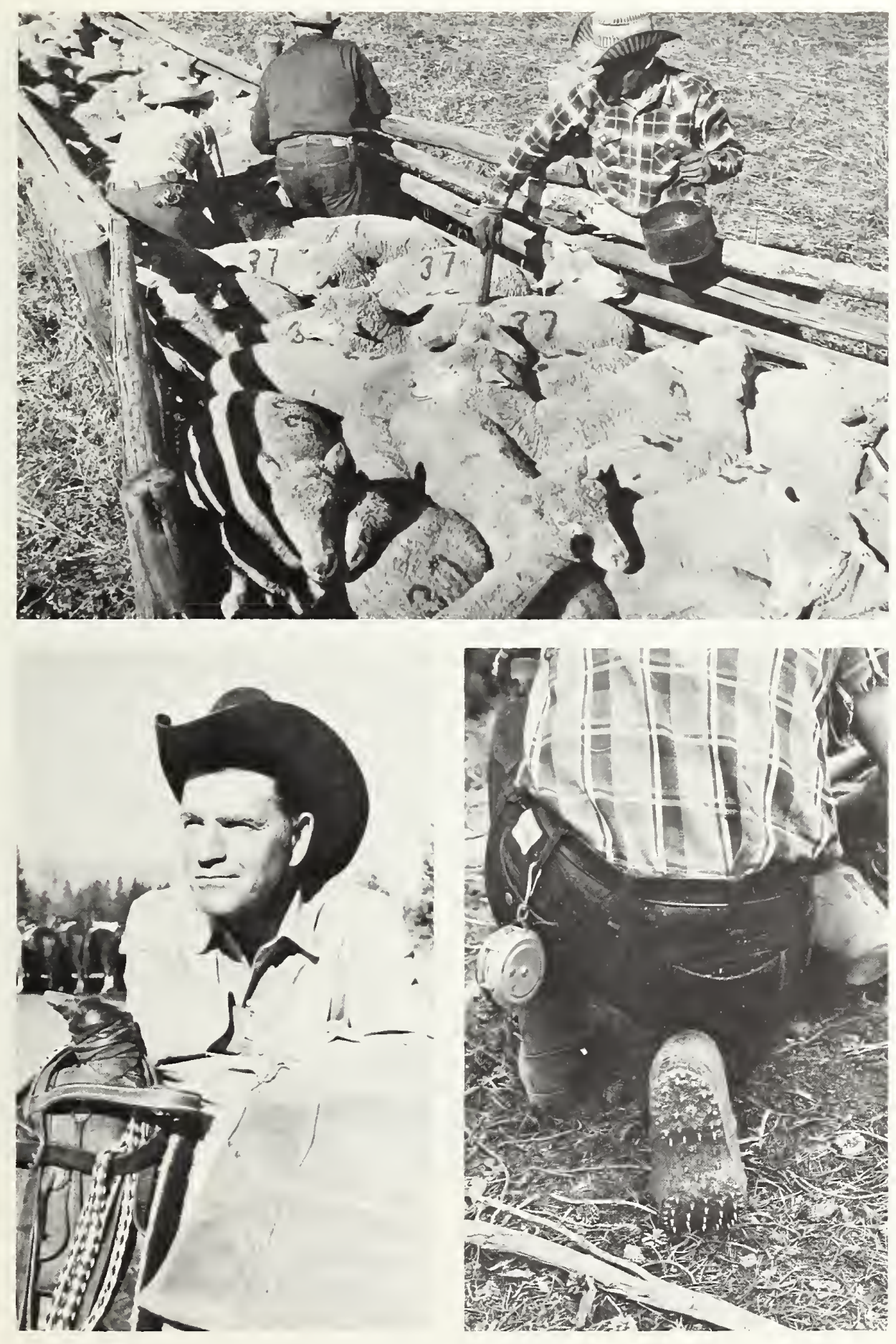

Marking sheep before they go to National Forest rangelands.

The hobnail boot of a sawyer. 
Regardless of how much modern man enjoys the comfort of his modern home, he has a basic instinct that draws him to the forest. There is clean fresh air to breath and scenery to enjoy. There are mountains to climb, trails to follow, and water for fishing, swimming, and boating. In the National Forests of the Intermountain Region, the winter brings miles and miles of snow, perfect for skiing and snowmobiling.

A great deal of planning goes into providing the outdoor experience sought by each person. Nature provides the setting. A team of forest managers is needed to design facilities in a way that enhances and protects the forest environment.

This is one of the areas where the touch of a landscape architect is needed. He can help design pleasant and harmonious changes so that the impact of people on the forest is little noticed. The landscape architect is a specialist on a team of many specialists, including foresters, soil scientists, hydrologists, engineers, geologists, range ecologists, and biologists.
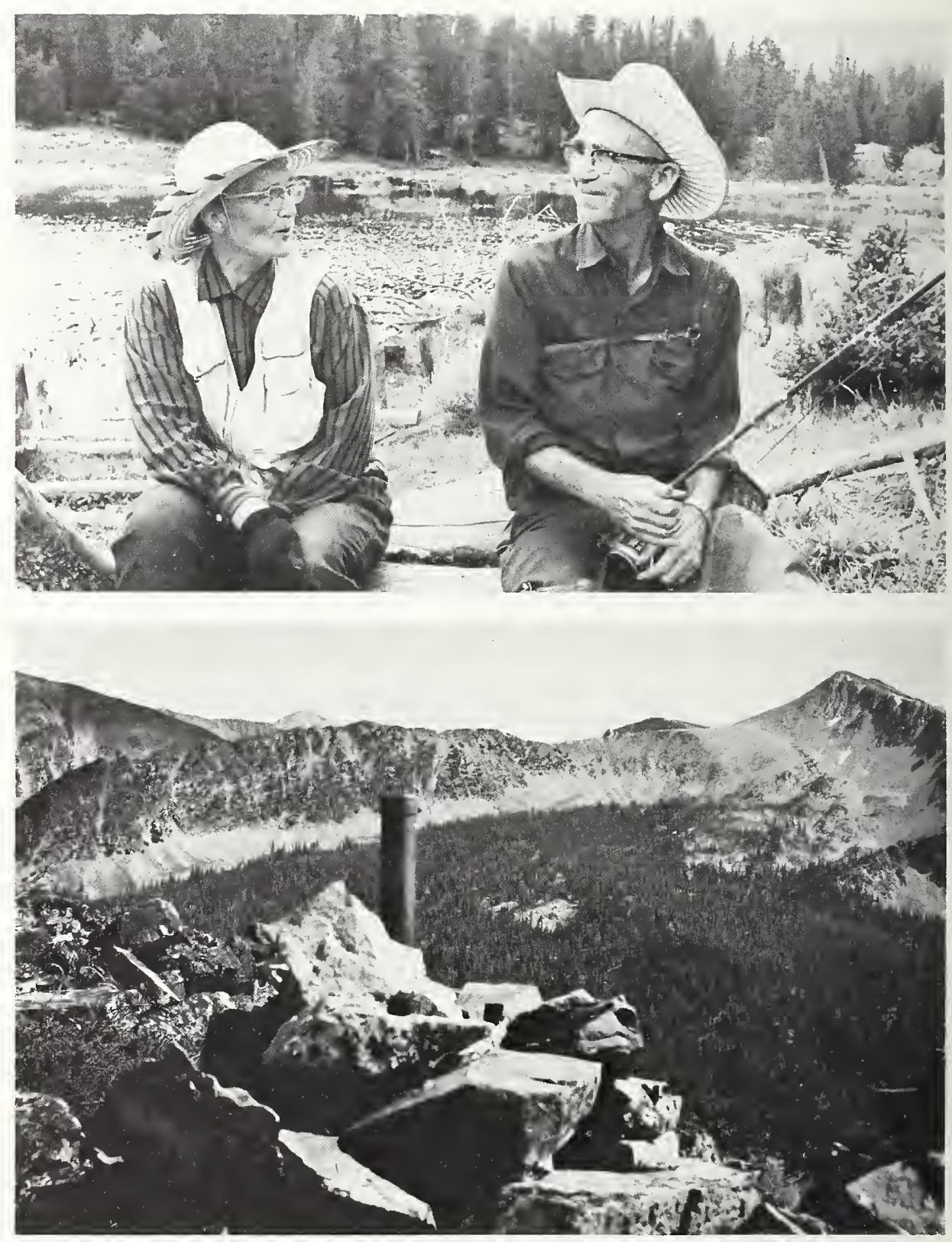

Original mileage post on the proposed Continental Divide Scenic Trail in Idaho. This trail would reach across the top of the continent, from Montana to New
Mexico. Government and state agencies, as well as user groups and conservation organizations are involved in planning the trail to meet the needs of travelers. 


\section{OPPORTUNITIES FOR \\ DISCOVERY}

In earlier times the role of education was to make the human population literate. Today the role of education is to make a literate population human. Thus, environmental education becomes an important job with which the Forest Service is involved.

Direct experience with the natural world helps children understand themselves and each other and their responsibilities to the environment. Forest Service personnel work with educators to provide opportunities for tomorrow's leaders to discover "the world in a grain of sand and heaven in a wild flower" - or to find in a simple lichen the key to survival.

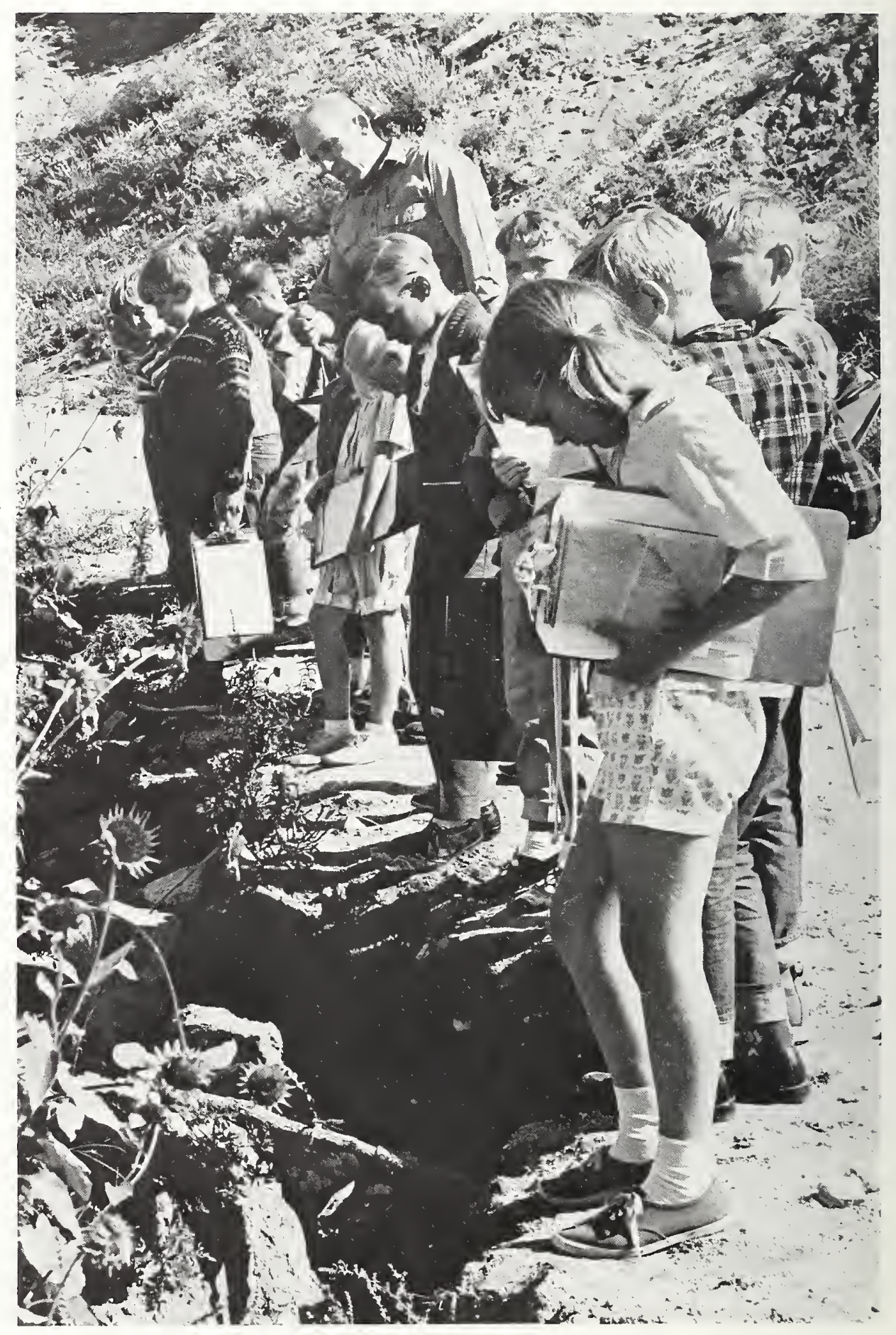




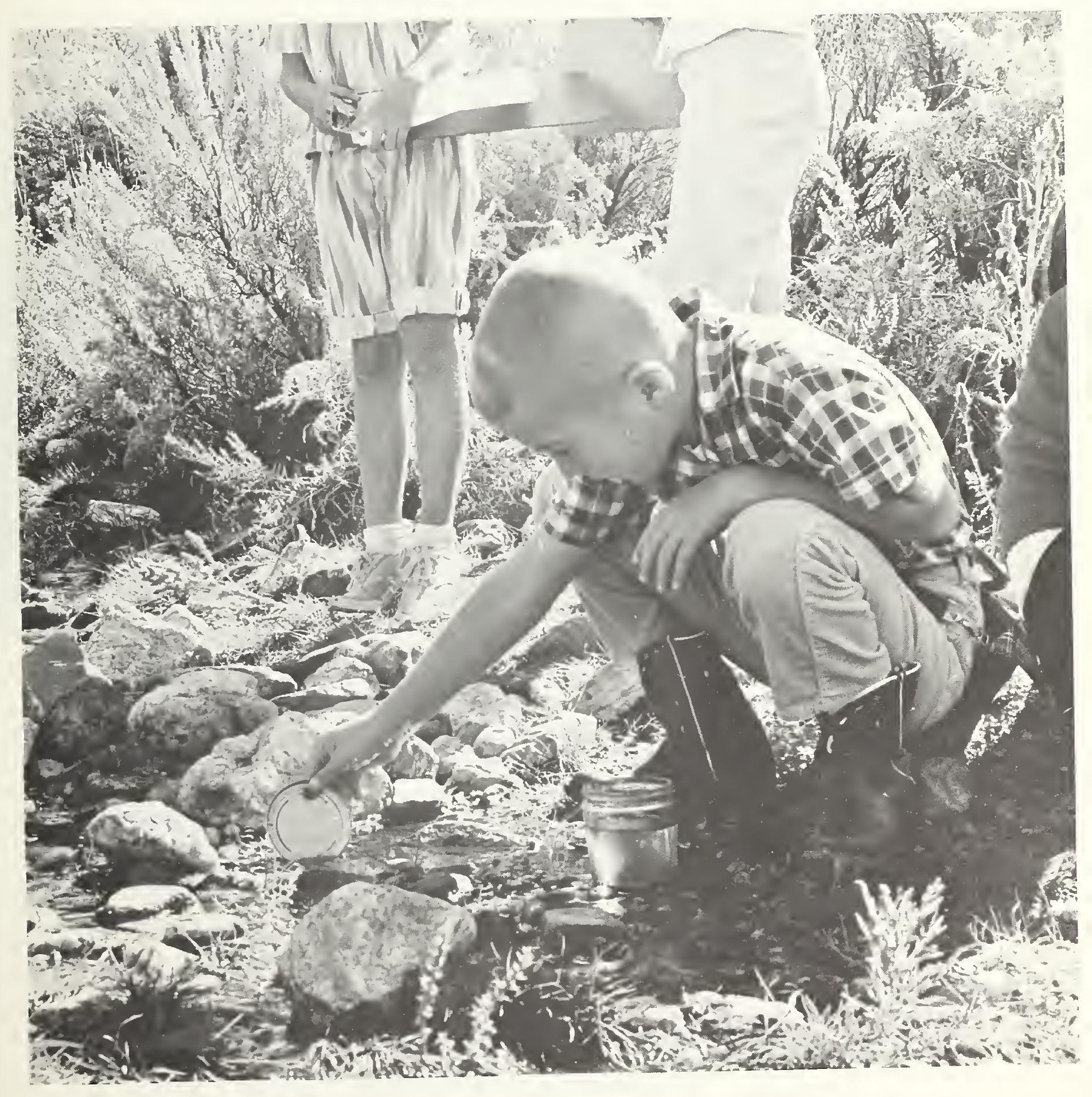


By nature, women are concerned with their environment. The quality of their homes and their families' lives depends upon it. And, by nature, women are eager to participate in constructive activity in their local communities and the world at large. Our work with women's organizations is an effective way to provide opportunities for environmental studies and to benefit from their wise counsel and advice.

Demonstrating their desire to work for a better world, women leaders from Utah, Montana, Washington, Colorado, Wyoming, and Idaho gathered at Redfish Lake in ldaho for a conservation convocation. They exchanged ideas on what could be done to maintain and improve the environment.

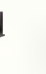

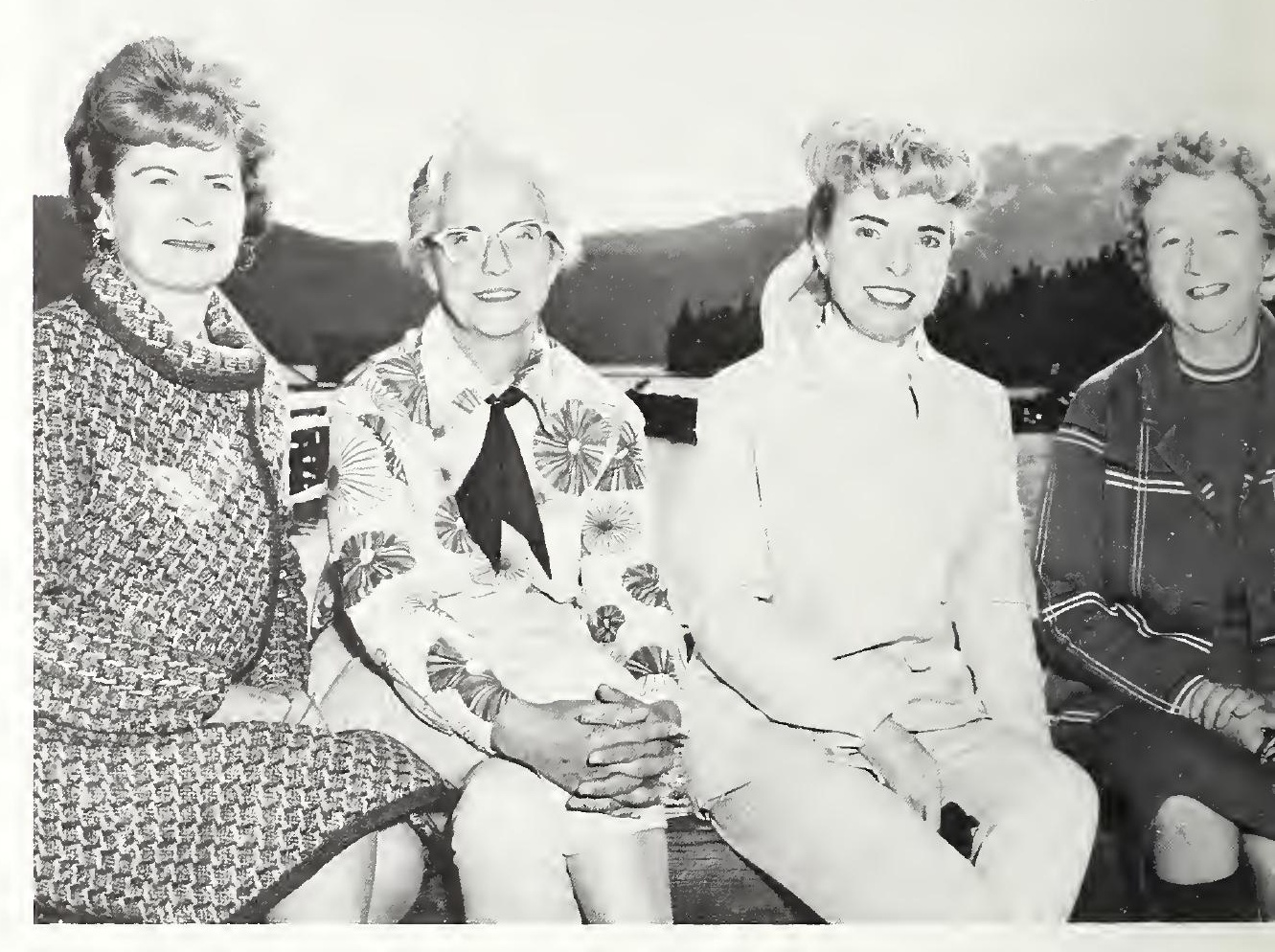

"You must convince the people of the truth - that the success of homemakers depends in the long run upon the wisdom with which the nation takes care of its forests." President Theodore Roosevelt 


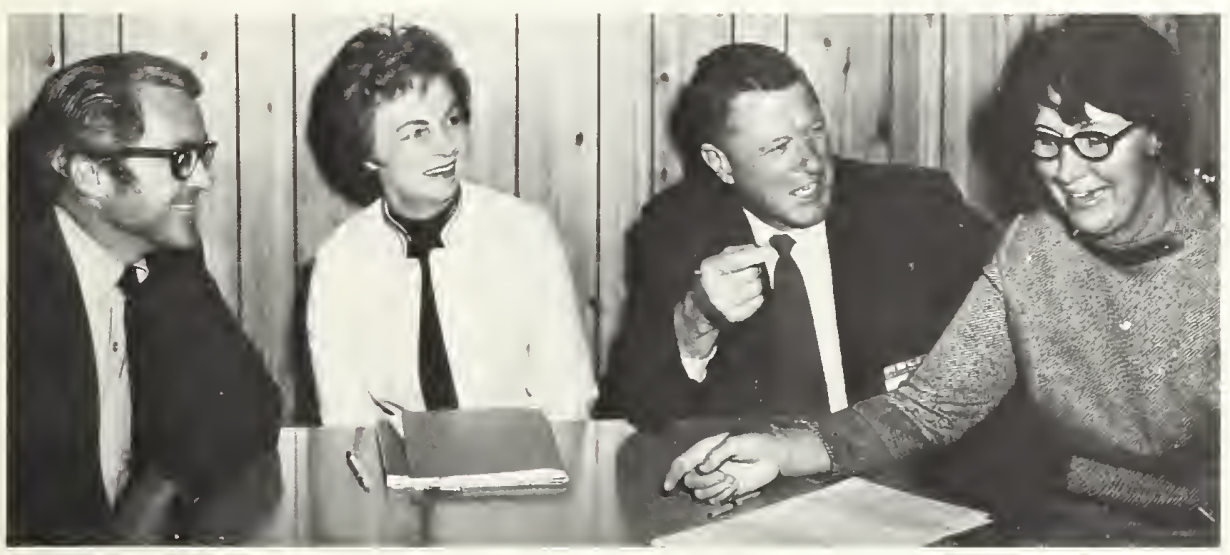

Groups discussed the role of women as "Architects of Our Environment."

The women recognized

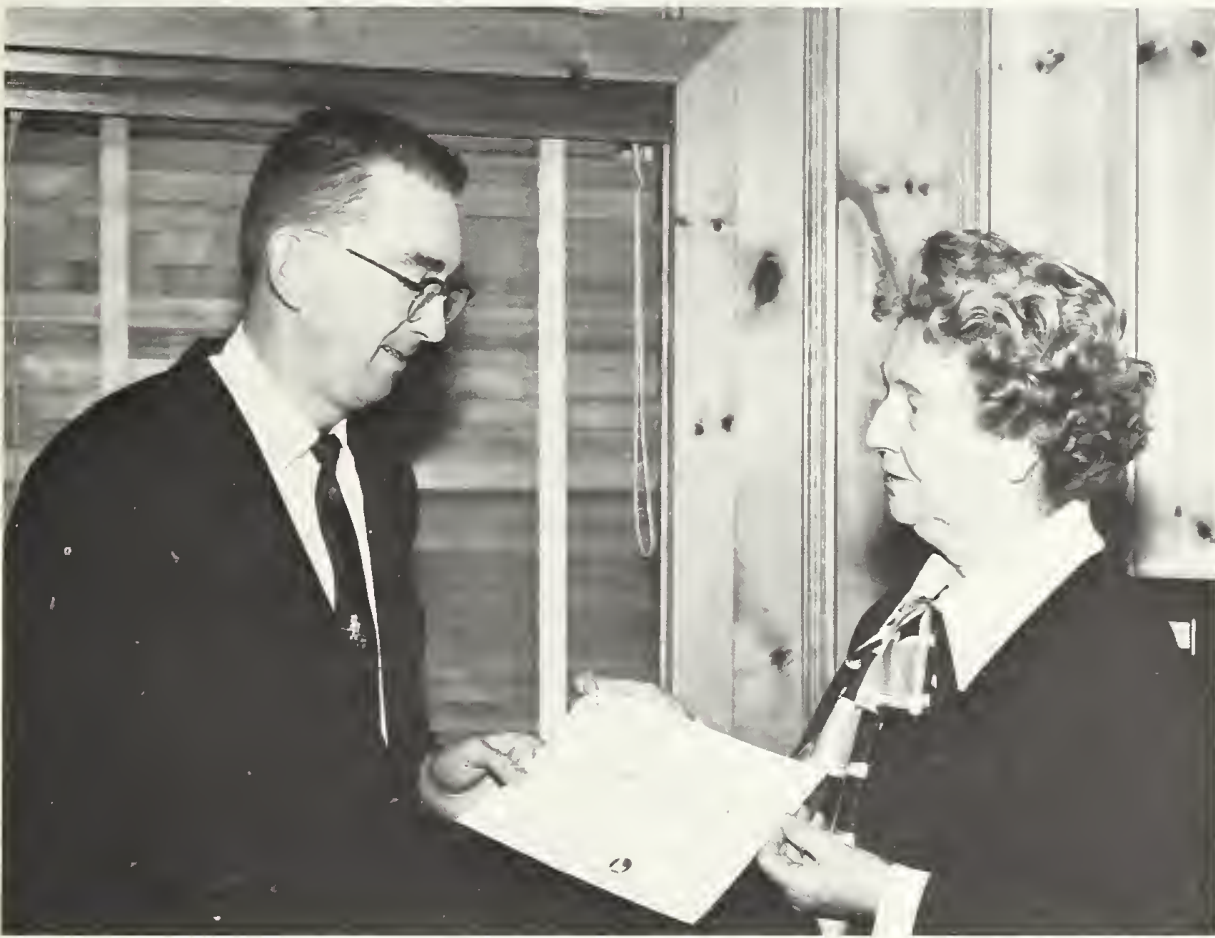
conservation activities of the State of Idaho. 
Today, the role of the Forest Service in improving the total environment is more difficult to define than in earlier days. Like ripples in a pool, our activities have ever widening influence.

An interpretive exhibit can reach far beyond the boundaries of time and space to make the pages of history come alive. A program for employing and training youth in an economically depressed area has far-reaching benefits, possibly for many generations to come. Working with private land owners to develop rural and urban improvements strengthens the economic base of an entire community, and in so doing strengthens the Nation. Helping build a healthy productive countryside is a step toward solving the problems of the cities.

We must be sensitive to the problems and needs of a changing society. Through an exchange of knowledge with other agencies and individuals, we join in plans for the social and economic well-being of the American public.
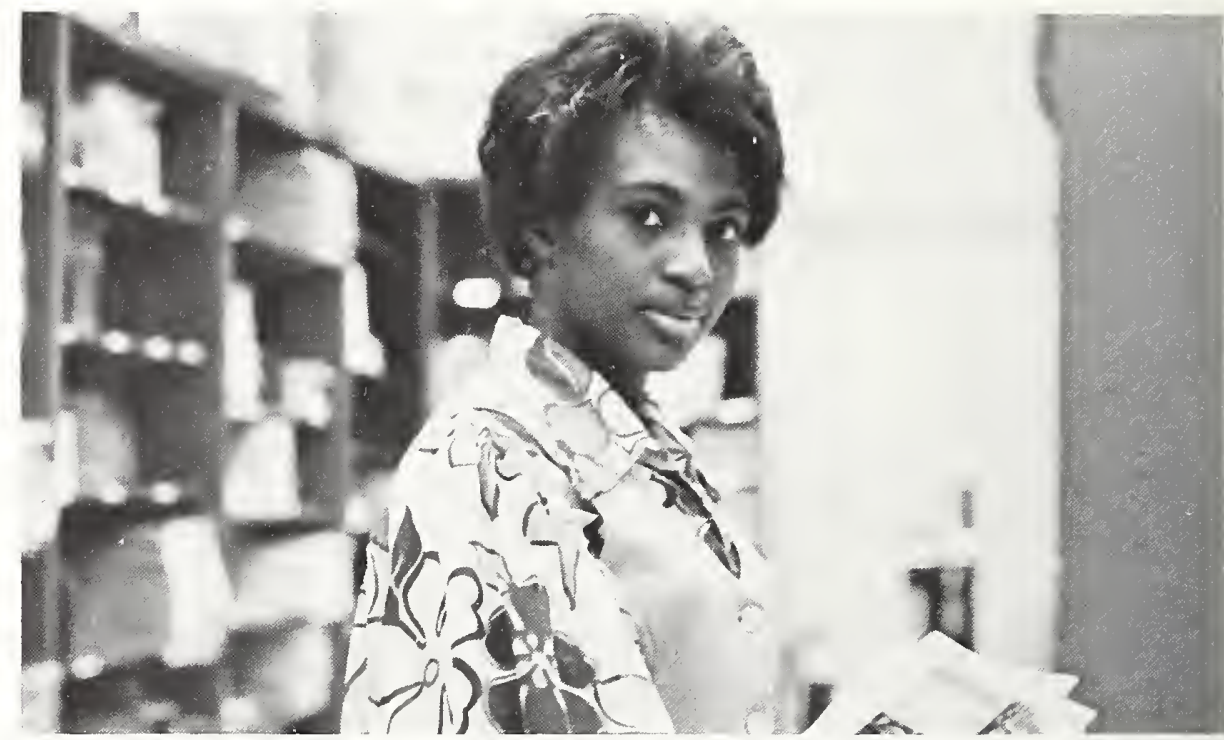

A college student works part time in Forest Service information.

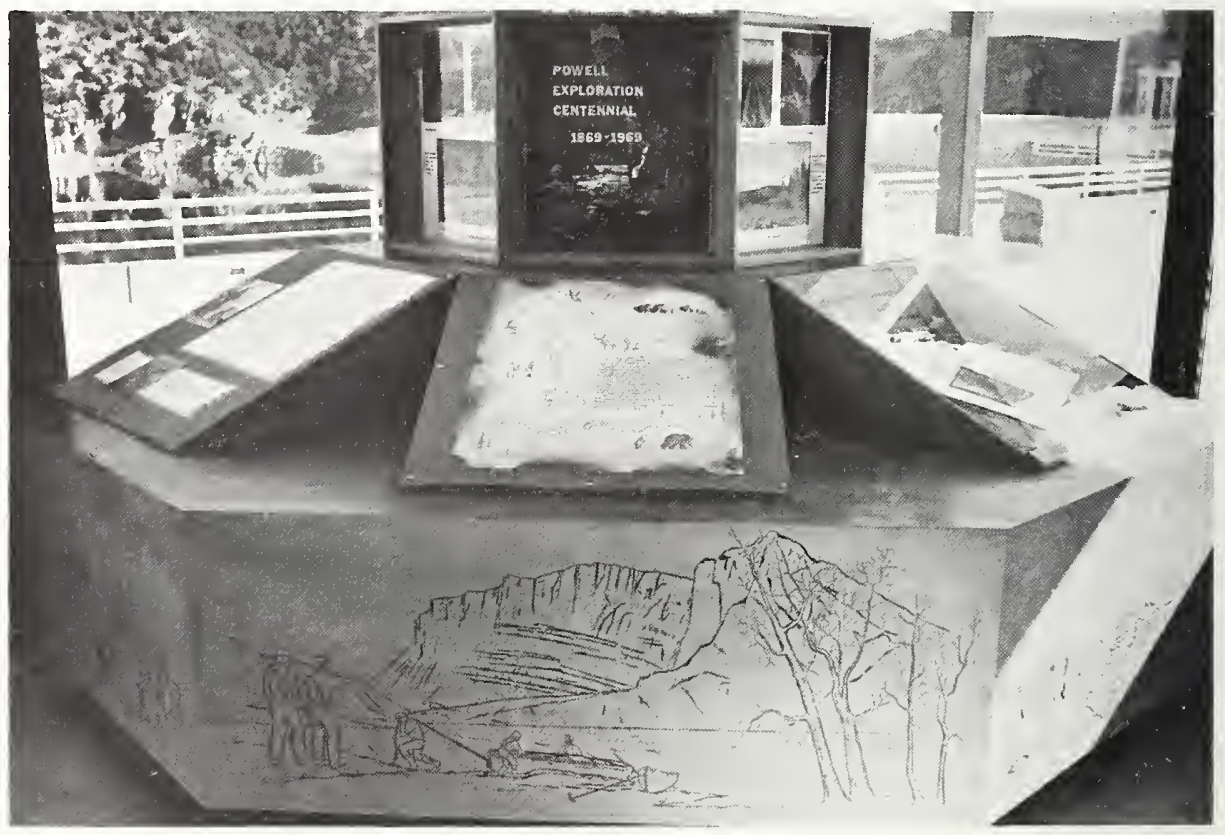

An exhibit built especially for the Jolin Wesley Powell Centennial. It was placed in the Visitor Center at Flaming Gorge National Recreation Area, overlooking the canyon explored by Powell 100 years ago. 

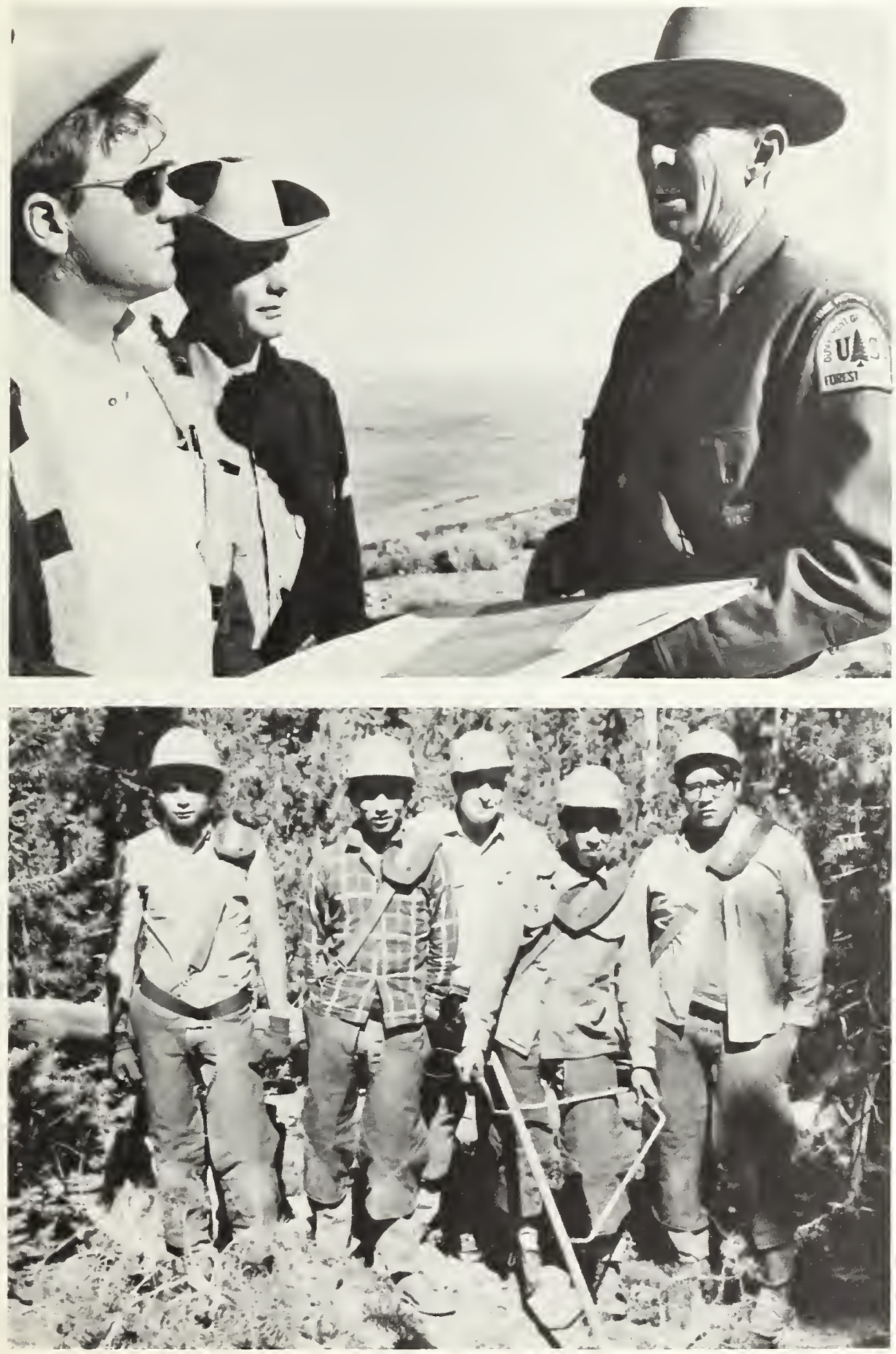

Forest Ranger discusses a recreation development with a private land owner and a real estate broker. The land in Kingston Canyon is part of the Central Nevada Development Program and lies adjacent to the Toiyabe National Forest boundary.

Six Uintall Basin youths thinned 140 acres of overstocked young trees during their summer vacation. Their services were obtained by the Forest Service through the Neighborhood Youth Corps Program sponsored by the Ute Indian Tribe. 
Among all the earth's inhabitants, man alone can study the past, relate it to the present, and help determine his destiny. And we are told that man is the only creature that is conscious of a responsibility to other forms of life. How well this responsibility is redeemed depends upon the degree that we understand the needs of the total environment.

Communication is the key to understanding. In keeping lines of communication open, there must be opportunities for people to speak out and to listen - to reason together. Opportunities for exchanging opinions and ideas exist in the forms of field trips on National Forests, informal chats between Forest Officers and interested users, and public meetings where all sides of a problem are presented.

Rural people as well as city people are invited to express their viewpoints about management of National Forests. The public can become involved in Forest Service objectives, and the resources of National Forests can be managed for the good of all segments of society.

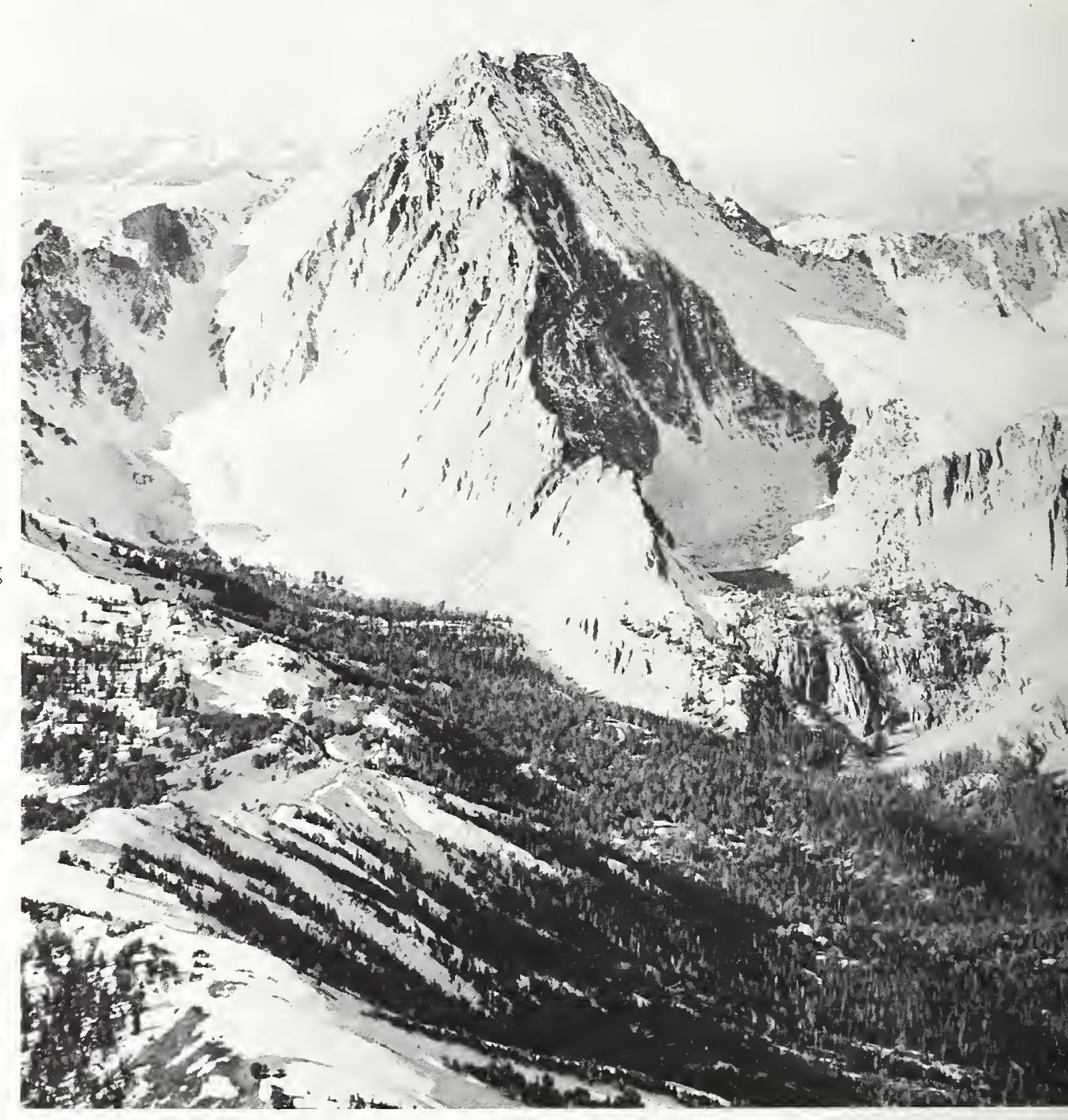




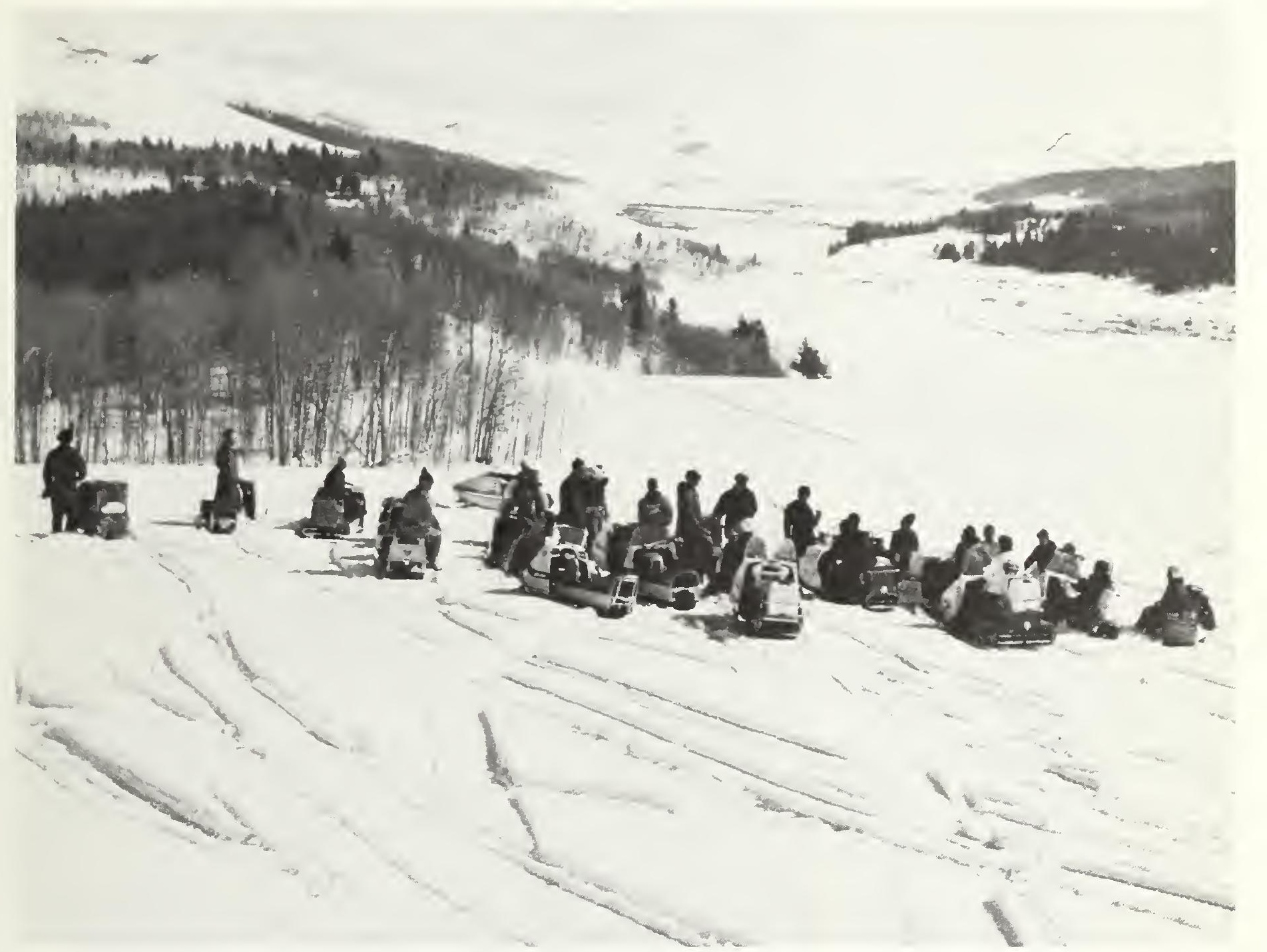

A "now scene" on a trail to the past. Forest Service and Bureau of Land Management personnel, with writers, resort owners, and manufacturers traveled by snowmobile and discussed plans for the Lander Trail Cut-off on the Caribou and Bridger National Forests. In
1969, their snowmobiles left tracks much different from those made by covered wagons a century ago. 
When man looks back from tomorrow, what will remain of today? Will there be clean air, pure water, productive forests, and some land without scars? Will today's endangered species have survived each making its unique contribution to biological history? Will remnant plant communities remain intact, as we see them today and as they were found in an earlier time?

The answers to our questions are being written now - by all of us. Part of the answers will be found in proper management of our National Forests. All of the answers will be found in the degree that people learn to live in harmony with each other and with their land.

Lake Tahoe - where people are working together to preserve purity of water and beauty of scene.

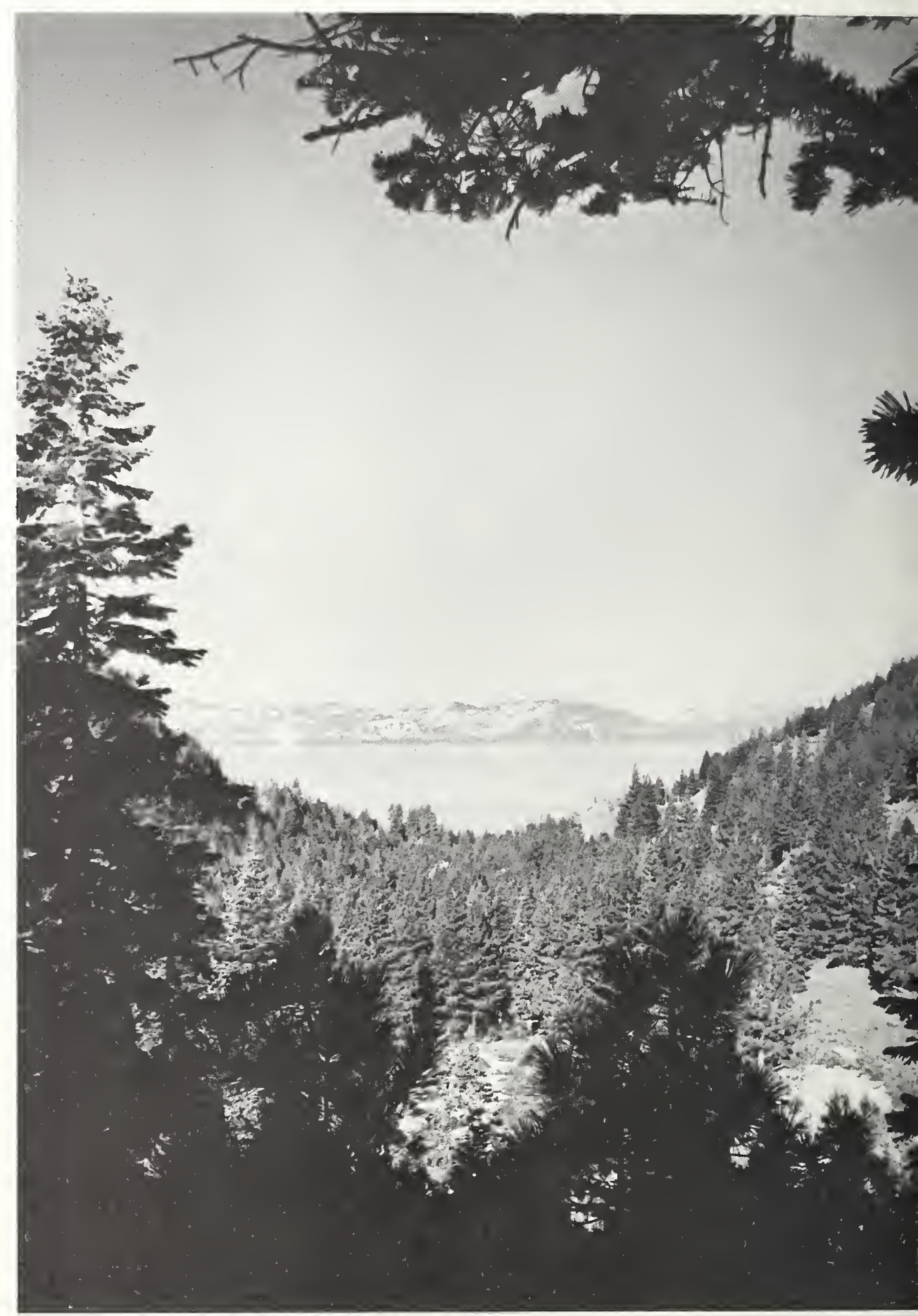




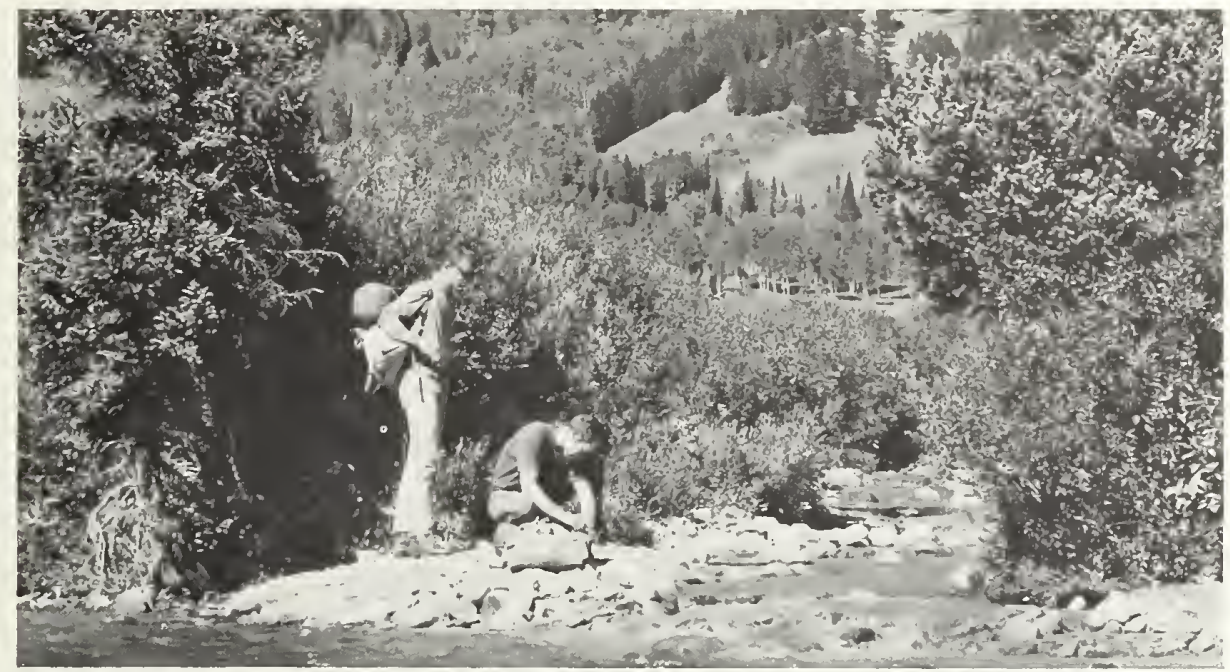

Today a boy can hike into wild country like this in the Teton National Forest and find sparkling streams of water. What will a boy find tomorrow?

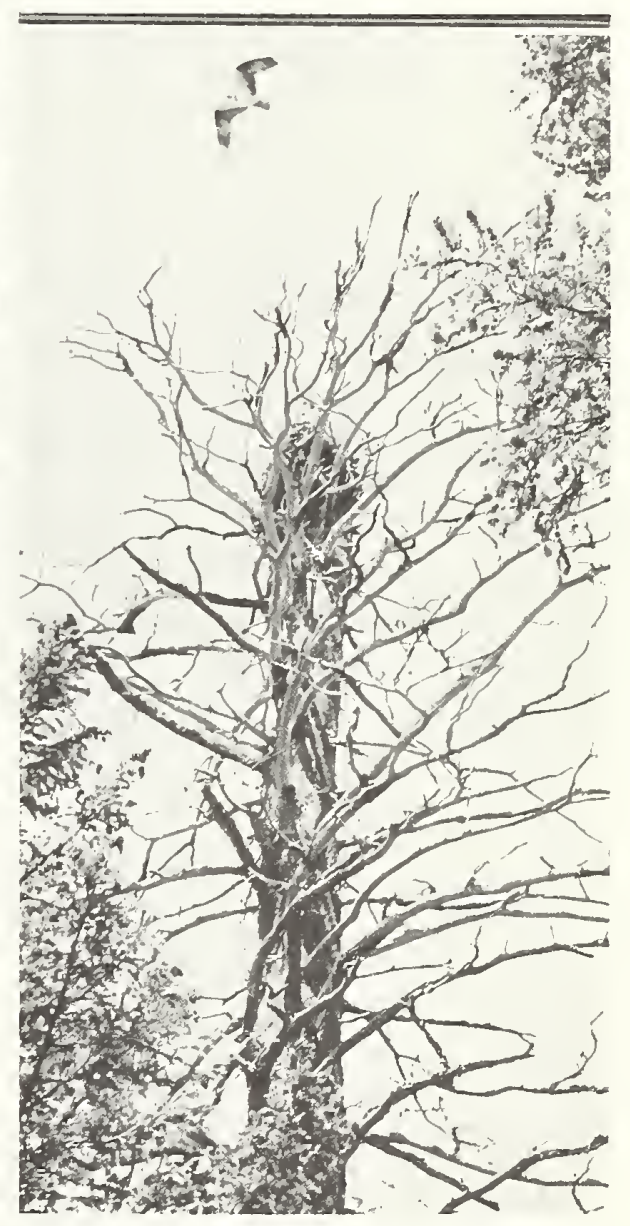

An osprey flies from its nest in a dead treetop. Will its descendants inhabit the world of tomorrow? Or will man's indifference cause a break in the chain of life? 
Regional Headquarters:

32425 th Street, Ogden, Utah 84401

Floyd lverson

Regional Forester

Gordon L. Watts

Deputy Regional Forester

A. E. Smith

Chief, Division of Information and Education

Oliver Cliff

Chief, Division of Range Management

D. M. Gaufin

Chief, Division of Wildlife Management

Marlin C. Galbraith

Chief, Division of Timber Management

Richard L. Harris

Chief, Division of Recreation and Lands

S. L. Cuskelly

Chief, Division of Soil and Water Management

Robert S. McBride

Chief, Fire Control, State and Private Forestry

Neil B. Opsal

Chief, Division of Personnel Management

Lennart E. Lundberg

Toiyabe

Chief, Division of Operation

James M. Usher

Regional Engineer

Clyde E. Jones

Wasatch

\section{Ashley \\ Boise \\ Bridger}

Cache

Caribou

Challis

Dixie

Fishlake

Humboldt

Manti-LaSal

Payette

Salmon

Sawtooth

Targhee

Teton

Uinta

Fiscal Agent

\section{NATIONAL FOREST}

437 East Main Street Vernal, Utah 84078

1075 Park Boulevard

Boise, 1daho 83706

Forest Service Building

P. O. Box 31

Kemmerer, Wyoming 83101

429 South Main Street

P. O. Box 448

Logan, Utah 84321

427 North Sixth Avenue

P. O. Box 4189

Pocatello, 1daho 83201

Forest Service Building

Challis, 1daho 83226

500 South Main Street

Cedar City, Utah 84720

170 North Main Street

Richfield, Utah 84701

976 Mountain City Highway

Elko, Nevada 89801

350 East Main Street

Price, Utah 84501

Forest Service Building

P. O. Box 1026

McCall, 1daho 83638

Forest Service Building

P. O. Box 729

Salmon, Idaho 83467

1525 Addison Avenue East Twin Falls, 1daho 83301

420 North Bridge Street

St. Anthony, Idaho 83445

Forest Service Building

P. O. Box 979

Jackson, Wyoming 83001

Post Office Building

P. O. Box 1331

Reno, Nevada 89504

Federal Building 88 West 100 North

P. O. Box 1428

Provo, Utah 84601

4438 Federal Building

125 South State Street

Salt Lake City, Utah 84111
SUPERVISOR

A. R. McConkie

H. E. Ahlskog

W. O. Deshier

M. I. Bishop

D. A. Schultz

G. W. Carìson

A. F. Wright

R. C. Christensen

R. A. Rowen

G. F. McLaughlin

W. B. Sendt

F. E. Powers

E. A. Fournier

R. H. Tracy

R. L. Safran

E. C. Maw

C. S. Thornock

C. P. St. Jolın 


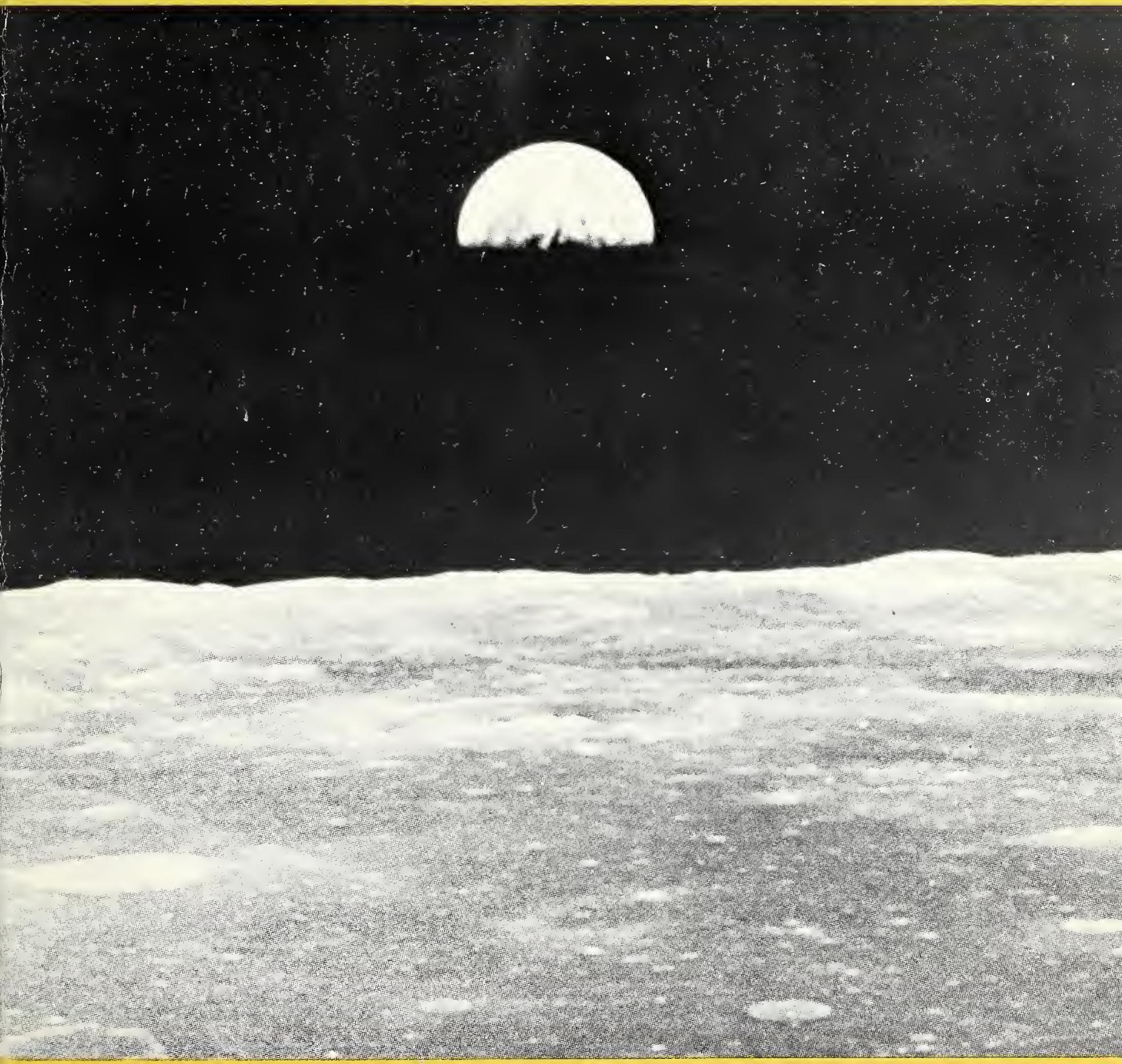

The resources of our planet must be wisely used, as man moves toward dimensions yet undreamed. 
"The Forest Service of the U.S. Department of Agriculture is dedicated to the principle of multiple use management of the

Nation's forest resources for sustained yields of wood, water, forage, wildlife, and recreation. Through forestry research, cooperation with the States and private forest owners, and management of the National Forests and National Grasslands, it strives - as directed

by Congress - to provide increasingly greater service to a growing Nation." 